$$
\begin{aligned}
& \text { 震 }
\end{aligned}
$$

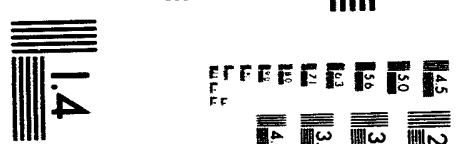

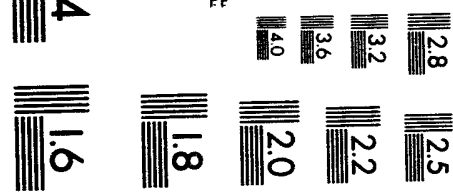



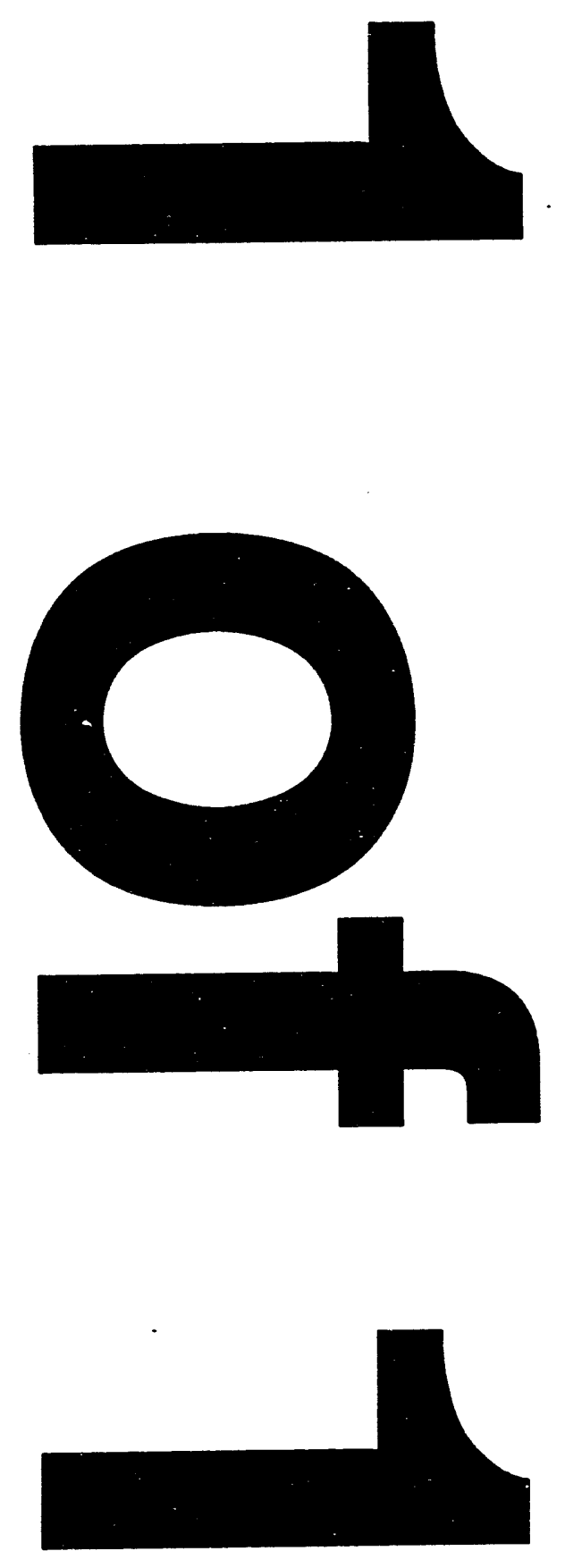
NUREG-1427

\section{Regulatory Analysis for the Resolution of Generic Issue 143: Availability of Chilled Water System and Room Cooling}

Manuscript Completed: October 1993

Date Published:December 1993

V. T. Leung

Division of Safety Issue Resolution Office of Nuclear Regulatory Research U.S. Nuclear Regulatory Commission Washington, DC 20555-0001

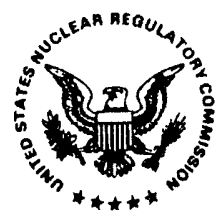




\section{ABSTRACT}

This report presents the regulatory analysis for Generic Issue (GI-143), "Availability of Chilled Water System and Room Cooling." The heating, ventilating, and air conditioning (HVAC) systems and related auxiliaries are required to provide control of environmental conditions in areas in light water reactor (LWR) plants that contain safety-related equipment. In some plants, the HVAC and chilled water systems serve to maintain a suitable environment for both safety and non-safety-related areas. Although some plants have an independent chilled water system for the safety-related areas, the heat removal capability often depends on the operability of other supporting systems such as the service water system or the component cooling water system. The operability of safety-related components depends upon operation of the HVAC and chilled water systems to remove heat from areas containing the equipment. If cooling to dissipate the heat generated is unavailable, the ability of the safety-related equipment to operate as intended cannot be assured. Typical components or areas in the nuclear power plant that could be affected by the failure of cooling from HVAC or chilled water systems include the (1) emergency switchgear and battery rooms, (2) emergency diesel generator room, (3) pump rooms for residual heat removal, reactor core isolation cooling, high-pressure core spray, and low-pressure core spray, and (4) control room. The unavailability of such safety-related equipment or areas could cause the core damage frequency (CDF) to increase significantly. 


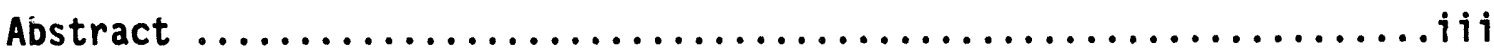

Executive Summary $\ldots \ldots \ldots \ldots \ldots \ldots \ldots \ldots \ldots \ldots \ldots \ldots \ldots \ldots \ldots \ldots \ldots$

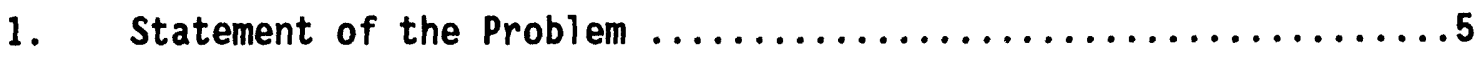

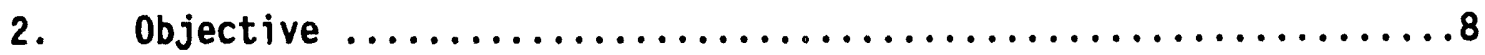

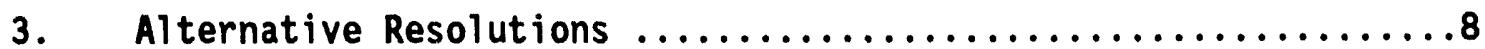

3.1 Description of Proposed Resolution Element $\ldots \ldots \ldots \ldots \ldots .8$

3.1.1 Perform Room Heat Up Calculations and Thermal Fragility Analyses ..............8

3.1.2 Review the HVAC/Room Cooler System Design ........9

3.1.3 Enhance the Preventive Maintenance and Testing Programs $\ldots \ldots \ldots \ldots \ldots \ldots \ldots . . .9$

3.1.4 Improve Emergency Procedures .................

3.1.5 Install Remote Room Temperature Monitors

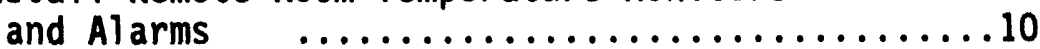

3.1.6 Install Portable Air Coo?ing Equipment ............10

3.1.7 Install Thermal Barriers Between Heat-Producing and Thermal-Sensitive Components ............11

3.1.8 Install a Permanent Backup Cooling System .........11

3.1.9 Test Electrical Cabinet Temperature $\ldots \ldots \ldots \ldots \ldots \ldots . .11$

3.1.10 Initiate an Airflow Test Program ..............12

3.2 Proposed Alternative Resolutions $\ldots \ldots \ldots \ldots \ldots \ldots \ldots \ldots \ldots \ldots \ldots \ldots \ldots$

3.2.1 Alternative 1 - No Action .....................

3.2.2 Alternative 2 - Perform Fragility Analys is, System Design Review, Maintenance and Testing Program, and Improve Emergency

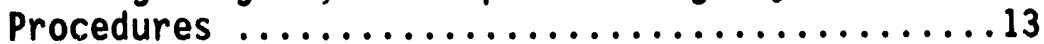

3.2.3 Alternative 3 - Combine Alternative 2 with Installing Remote Temperature Monitors or Alarms and Portable Air Cooling Equipment ......13

3.2.4 Alternative 4 - Combine Alternative 3 with Installation of Thermal Barriers, Permanent Backup Cooling System, Cabinet Temperature Test, and Airflow Test Program ..............13

4. Technical Findings ....................................

4.1 Identify the Vulnerabilities of Safety-Related

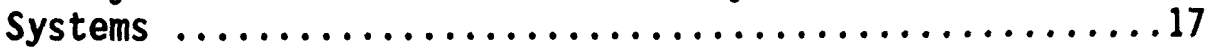

4.1.1 Review and Evaluation of Open Literature .........17

4.1.2 Review of Licensee Event Report (LER) ..........18

4.2 Established a List of Representative Plants ............21

4.3 ESF Dependencies on Room Coolers and Affected

Accident Sequences ...............................31

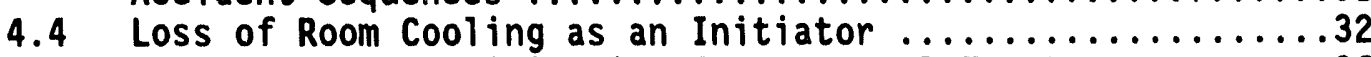

4.4.1 CDF Quantification for Internal Events ..........36

4.4.2 Public Risk Quantification for Internal

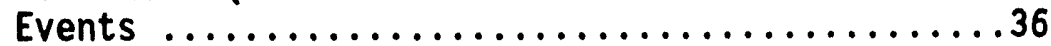




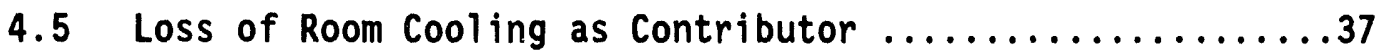

4.6 Assessment of Effect CDF from External Events ...........38

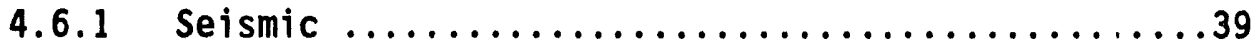

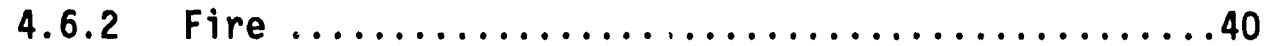

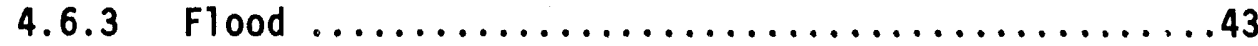

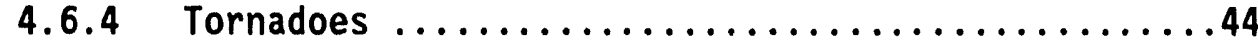

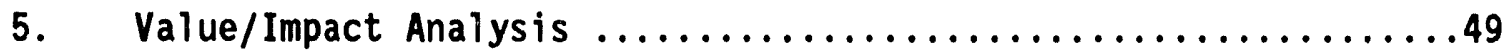

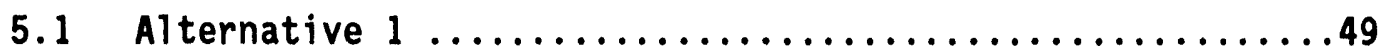

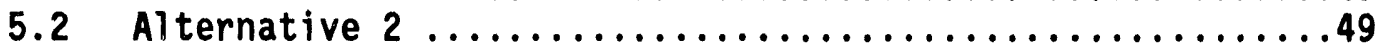

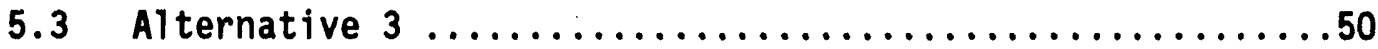

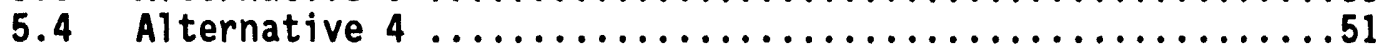

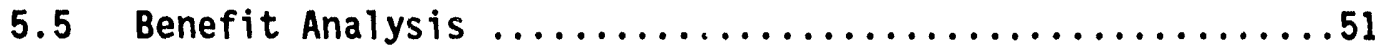

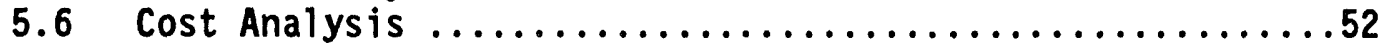

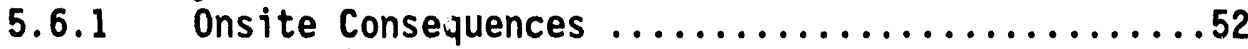

5.6.1.1 0ccupational Exposures ...................52

5.6.1.2 Averted 0ccupational Exposures from a

Reduction in Accidents .................52

5.6.1.3 Averted Onsite Property Damage .............53

5.6.1.4 Averted Public Property Damage ..............53

5.6.1.5 Total Costs for Resolution

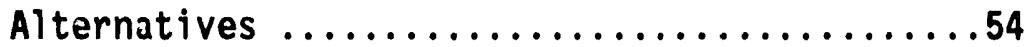

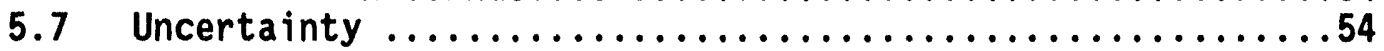

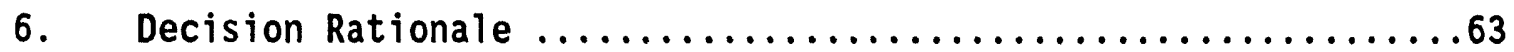

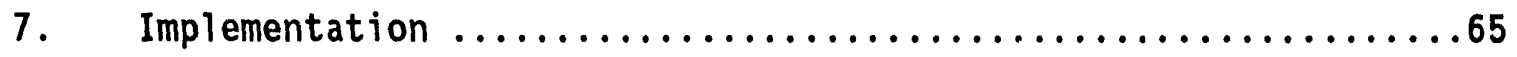

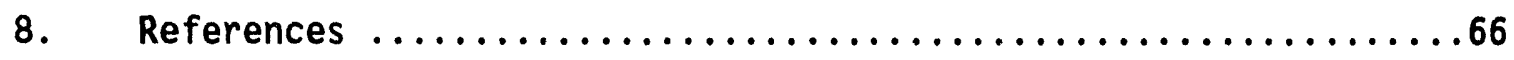




\section{LIST OF TABLES}

Table ES-1 Summary of CDF and Public Risk Results

PAGE

for Representative Plants ...................

Table ES-2 Summary of Affected CDF and Public Risks of Alternative Resolutions ....................

Table 3.1 Matrix of Vulnerabilities vs. Resolution

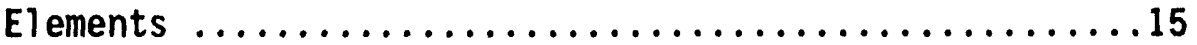

Table 3.2 Summary of Alternative Resolutions to GI-143 ..........16

Table 4.1 Number of Records Reviewed in Each Applicability

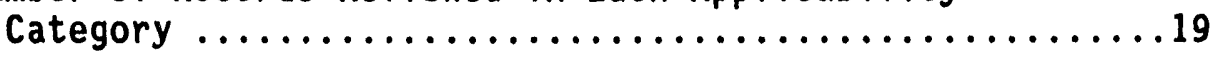

Table 4.2 HVAC and Room Cooler Failure Data from NUCLARR ........20

Table 4.3 LER Data for Room Cooler and HVAC Failures Designated as

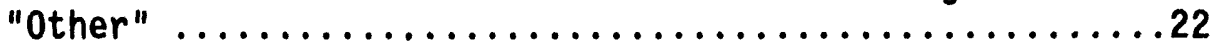

Table 4.4 Common Cause Failure Data from LER Reviews of

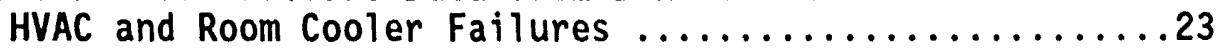

Table 4.5 HVAC/Room Cooler Malfunction Frequencies for Each

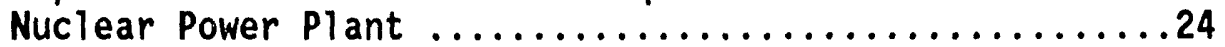

Table 4.6 Room Cooler Data for a Typical PWR ................28

Table 4.7 Room Cooler Data for a Typical BWR .................29

Table 4.8 Reliability Data for Area/Room Coolers Based

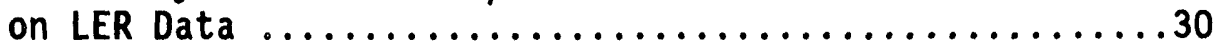

Table 4.9 Events Involving Room Cooler Failures Identified

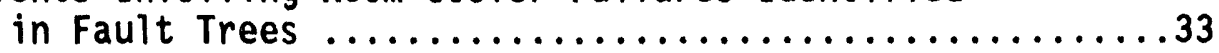

Table 4.10 Room Cooler Initiating Event Frequencies .................

Table 4.11 Assessed Mean CDF with Room Cooler Failure as

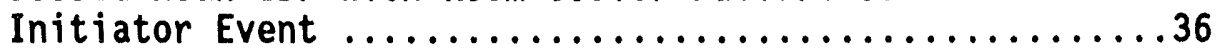

Table 4.12 Affected CDF and Public Risk for the Representative Plants from Room Cooler Initiator ....................

Table 4.13 Summary of Affected CDF and Public Risk Results for the Representative Plants from Internal Events (HVAC as Initiator and Contributor) .38 


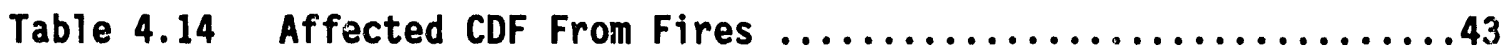

Table 4.15A Summary of Flood-Induced Affected CDF for $W$ and CE PWRs and GE BWRs $\ldots \ldots \ldots \ldots \ldots \ldots \ldots \ldots . \ldots 45$

Table 4.15B Summary of Flood-Induced Affected CDF for a B\&W PWR ...........................................46

Table 4.16 Summary of Affected CDF due to External Everits ........47

Table 4.17 Summary of Affected Public Risk Values due to External

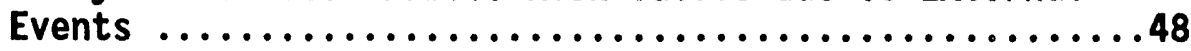

Table 5.1 Summary of CDF and Public Risks of Alternative Resolutions .................................55

Table 5.2 Estimated Occupational Exposures for Implementation, Operation, and Maintenance of Resolution Alternatives .................................56

Table 5.3 Summary of Averted Onsite Property Damage Costs .......57

Table 5.4 Summary of Averted Offsite Property Damage Costs ......58

Table 5.5 Summary of Cost Estimates for Each Resolution Element ....................................59

Table 5.6 Summary of Benefits of Alternative Resolutions $\ldots \ldots \ldots 60$

Table 5.7 Summary of Per-Plant and Total Costs for Each Resolution Alternative ........................61

Table 5.8 Best Estimate Value: Impact Ratios (\$/person-rem)....62 


\section{EXECUTIVE SUMMARY}

This report provides supporting information, including a value/impact analysis, for the Nuclear Regulatory Commission's (NRC's) resolution of Generic Issue 143, "Availability of Chilled Water System and Room Cooling." GI-143 is concerned with the availabi?ity of cooling services provided by the heating, ventilation, and air conditioning (HVAC) room cooling system and related auxiliaries to control the adverse effects caused by high temperature in areas containing safety-related equipment.

The objectives of the GI-143 program were to evaluate the adequacy of the HVAC and chilled water systems in existing light water reactor (LWR) power plants. Specifically, the evaluation included (1) identifying areas that are particularly vulnerable to loss of the HVAC/room cooler, (2) estimating the HVAC and chilled water system's failure frequencies leading to a loss of heat removal capability from areas containing safety-related equipment, (3) determining the vulnerabilities of safety-related systems and components from HVAC/room cooler failure that are reflected in actual operating experience, (4) estimating the core damage frequency (CDF) and public risks associated with HVAC/room cooler failure, (5) determining the benefits of providing alternative means of controlling high temperature that could substantialiy increase the plant's safe-shutdown capability, and (6) assessing the benefits and costs of alternative ineasures for improving the overall reliability of safety function of the HVAC and chilled water system.

Technical assistance for this issue was provided by Pacific Northwest Laboratories (PNL). Scoping and screening analyses conducted by PNL indicated that there were no "generic" HVAC/room cooler designs among the population of U.S. nuclear plants. Each plant appeared to have a "tailor-made" HVAC/room cooling system designed to accommodate the characteristics of each plant, perhaps on the basis of space limitation and particular plant configuration. As a result, it was decided to select a plant from each vendor for the detailed CDF and public risk calculation. This selection would ensure that the results are applicable to a large fraction of plants and would help determine whether there are significant differences in CDF related to HVAC/room cooling or public risk among vendors or plant types, even though the HVAC/room cooler designs appear not to be vendor or plant-type specific (Ref. 1). Additionally, an assessment of HVAC/room cooler failure data was performed to select the plants for use in the detailed CDF and risk calculations (Ref. 1). Plant-specific HVAC/room cooler vulnerability was assumed to be proportional to the frequencies of Licensee Event Reports (LERs) involving HVAC/room coolers and other information found in the open literature. Based on these data, plants were selected in terms of vulnerabilities to HVAC/room cooler failures. These plants represent a wide range of site environmental conditions, including hot dry desert and hot humid climates. Generic insights were also developed on the applicability of potential high CDF accident sequences found in the literature to the population of nuclear power plants.

An assessment was performed to develop insights on the applicability of these plants' designs and HVAC system configurations to other LWRs. The identified deficiencies ranged from design inadequacies to deficient operating, maintenance, and test procedures, including: 
- Installation errors during plant construction or modification,

- Test and maintenance errors, particularly failure to return safety-related HVAC components to service properly,

- Inadequate test procedures that result in failure to return safety-related HVAC components to service properly,

- Malfunctions of ventilation and fire dampers that lead to a total loss of room cooling to safety-related equipment rooms,

- Degradation of HVAC and room cooling system components because of inadequate attention to tests, inspections, or preventive maintenance,

- Design errors that resulted in inadequate ventilation air flow to certain safety-related equipment rooms and to certain areas within the rooms; for example, one identified design error involved locating one train of vital DC equipment in a switchgear room for the other train,

- Heavily loading individual divisions of vital DC control power whose components are sensitive to elevated room temperatures may result in failure of significant portions of safety-related system if the HVAC systems should fail.

In most cases, these were concluded to be plant-specific concerns. However, potentially generic deficiencies were identified, including the effects of ventilation and fire dampers on HVAC unavailability; underestimation of temperatures inside electrical cabinet; inadequate procedures for testing, inspections or maintenance; lack of emergency procedures; and inadequate training on HVAC and room cooling systems. This latter deficiency was not observed at the LWRs during the staff's site visits; however, it was judged to be a potential vulnerability because of the many incidents of such events described in various documents and LERs.

To add some perspective to the affected CDFs* calculated for the representative plants, a review and limited-scope quantitative evaluation of five additional PRAs were performed. The affected CDFs for these additional plants appear to be acceptable for comparison purposes.

The CDFs from internal events calculated for the nine plants (four representative plants and five additional plants) ranged from about $1.0 \mathrm{E}-07$ per reactor year to $1.0 \mathrm{E}-05$ per reactor year. (The main reason for the high affected CDF was that operator recovery factors were not applied to some critical accident sequences such as small loss-of-coolant accidents (LOCAs).) The arithmetic mean for all nine plants is approximately $4.6 \mathrm{E}-06$ per reactor year. It was then concluded that the four representative plants used in this analys is adequately represent the population of U.S. nuclear power plants in terms of CDF attributed to HVAC and room cooling system failure.

The external events analyses yielded affected CDF estimates of about 8.0E-06 per reactor year and public risk estimates of between 4 and 7 personrem per reactor year. These values are somewhat larger than the affected CDF 
and public risks associated with internal events. The external event analyses suggested no significant plant-specific anomalies that would lead one to believe that the HVAC/room cooling systems at the plants examined in this study are any more or less vulnerable than other plants to external events that may fail HVAC and room cooling equipment.

Key conclusions derived from the analyses (for both internal and external events) included:

- It was observed that the fire-induced CDF encompassed a much higher fraction of the total CDF than the corresponding fraction of the seismic-induced CDF. The main reason is that the HVAC and room cooling equipment, in general, is much less vulnerable to seismic-induced failures than other safety system components such as pumps, switchgears, and control valves. However, room coolers and HVAC equipment are as vulnerable to fire-induced failures, including fires affecting control and power cables, as other safety-related components.

- For both pressurized water reactors (PWRs) and boiling water reactors (BWRs), the seismic CDF is dominated by a few accident sequences. The dominant accident sequences primarily involve station blackout situations, although the exact causes of station blackout are somewhat different among plant types. Seismic-induced failures of pump suction sources (tanks) and emergency switchgear were the dominant contributors.

- Flood-induced sequences were observed to contribute approximately $10 \%$ of the affected CDF from external events. Similar to fires, flood effects are likely to be concentrated in certain areas of the plant.

Furthermore, it is quite unlikely that a flood could cause failure of HVAC equipment and not directly affect the operability of the equipment supported by the HVAC function.

- Tornadoes were insignificant because of the protection provided by plant structures from tornado-induced high winds and missiles. Tornadoes affect HVAC equipment similar to seismic events; i.e., it is unlikely that a tornado will fail HVAC equipment and not fail the safety-related equipment supported by the HVAC system. Therefore, failures of the safety components other than HVAC equipment will dominate the tornadoinduced CDF.

- The best-estimate CDFs for the representative plants from both internal and external events are relatively small, on the order of approximately 1.3E-05/RY, and none of the proposed alternatives are cost effective. Nevertheless, it appears that some plant-specific accident sequences at the plants 
appears that some plant-specific accident sequences at the plants may be as high as 1.0E-04/RY (Ref. 1).

In most cases, the high-frequency plant-specific accident sequences have been significantly reduced through hardware or operational changes. The probabilistic risk analyses (PRAs) being performed in support of the Individual Plant Examinations (IPES) have identified plant-specific anomalies and hardware configurations that have been or will be improved (Refs. 2, 3). Participation in the IPE program should be sufficient for licensees to identify and resolve plant-specific HVAC and room-cooler related concerns thiat are safety significant.

The total CDFs and public risks from both internal events and external events are presented in Tables ES.1 and ES.2. Table ES.2 shows the change in CDF and public risk that could be achieved by the four alternatives that were studied. Even the most stringent alternative does not satisfy the Commission's interim guidance established in SECY-91-270 for imposing new requirements.

Table ES-1. Summary of CDF and Public Risk Results for the Representative Plants

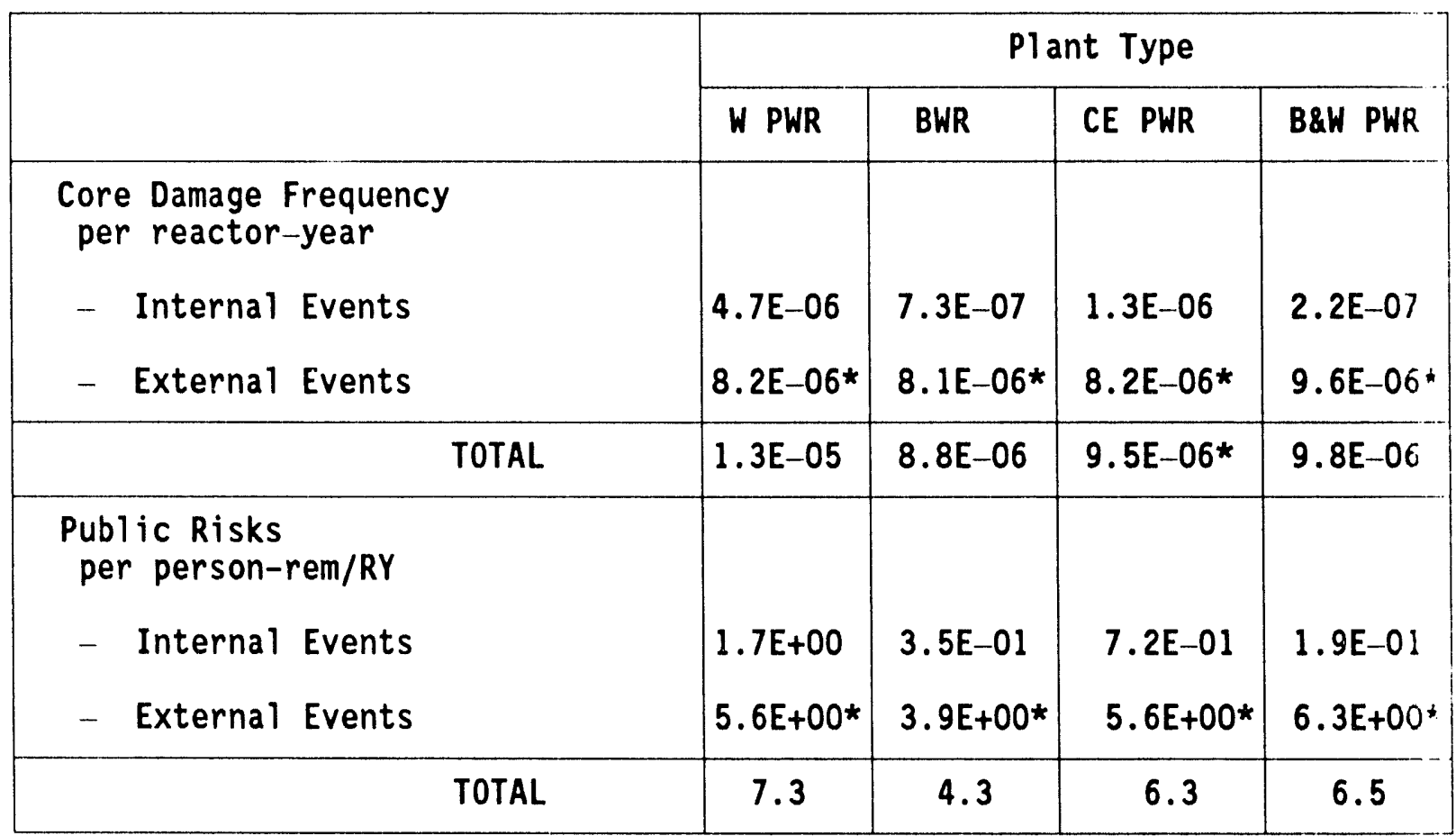

NOTE: Values marked with an asterisk $\left(^{*}\right)$ are point estimates. Remaining estimates are mean values. 
Table ES-2. Summary of Affected CDF and Public Risks of Alternative Resolutions

\begin{tabular}{|c|c|c|c|c|}
\hline Alternative & $\begin{array}{c}\text { Affected CDF, } \\
\text { Per RY }\end{array}$ & CDF & $\begin{array}{l}\text { Affected } \\
\text { Public Risk, } \\
\text { Person-rem/RY }\end{array}$ & $\begin{array}{c}\text { Public } \\
\text { Risk }\end{array}$ \\
\hline Base Case & $1.2 E-05$ & - & $7.28 E+00$ & - \\
\hline A1ternative 1 & N/A & N/A & N/A & N/A \\
\hline Alternative 2 & $9.9 E-06$ & $3.0 E-06$ & $6.0 E+00$ & $1.2 E+00$ \\
\hline A1ternative 3 & $7.8 E-06$ & $5.0 E-06$ & $4.9 E+00$ & $2.3 E+00$ \\
\hline Alternative 4 & $5.6 E-06$ & $7.0 E-06$ & $3.8 E+00$ & $3.5 E+00$ \\
\hline
\end{tabular}

\section{STATEMENT OF THE PROBLEM}

This Generic Issue is concerned with the availability of heat-removing capability and reliability of the HVAC, chilled water system, and related auxiliaries to maintain a suitable environment in areas containing safetyrelated equipment. The design and functional requirements of the HVAC and chilled water systems vary widely between the LWR power plants. In some plants, the system serves to maintain a prescribed environment for both saftey and non-safety-related areas. Even though some plants have an independent chilled water system for the safety-related areas, the heat-removal capability often depends on the operability of other supporting systems, such as the essential service water system or the component cooling water system.

In recent years, several nuclear power plants have experienced probleilis resulting from a partial or total loss of the HVAC system (Ref. 4). Numerous HVAC system failures have also been reported since 1981 (Ref. 1). Operabilily of safety-related components depends on the capability of the HVAC and chilled water systems to maintain the design environmental condition within the areas housing the equipment. If cooling is unavailable to remove the heat generaled in these areas, the ability of safety-related equipment to continuousiy operate as intended cannot be assured. Some typical components or areas in the nuclear power plant that could be affected by the failure of HVAC/room coolers inciude (1) the emergency switchgear room, (2) the emergency diesel generator room, (3) the pump rooms for residual heat removal (RHR), reactor core isolation cooling (RCIC), high-pressure core spray (HPCS), and low- 
pressure core spray (LPCS), (4) the control room, and (5) the cabinets housing safety-related electrical components. The unavailability of such safetyrelated equipment or areas could cause the CDF to increase significantly (Ref. 5).

Because corrective measures are often taken once the cooling system failures have been identified, the impact of these failures on the operability of the safety systems or components has not been reflected in many plantspecific PRAs. Consequently, HVAC and chilled water system vulnerabilities in such PRAs may not be considered to have a significant impact on plant safety. An example is one of the. PWR plants analyzed in Reference 6. Before this PRA was completed, improved testing of these cooling systems resulted in credit for significant risk reduction prior to completion of the NUREG-1150 program (Ref. 1). Such an improvement cannot be assumed for the rest of the LWR plants. Precurser events have shown that failure of the HVAC/room cooler could have significant impact on reactor safety if the faults were not recognized and corrected in a timely manner (Ref. 5).

In June 1984, while both units at a multi-unit LWR nuclear power plant site were operating at $100 \%$ power, a total loss of control area ventilation system occurred. Approximately 45 minutes later, the control room received numerous alarms on Unit 1 indicating high temperature in reactor coolant loop C. Alarms were also received for the pressurizer level on Unit 1. One hour into the event, the ventilation system was declared inoperable. Two hours into the event, the control room operators started to reduce power on both units as required by plant technical specifications. During this period, other alarms were also received on both units. At approximately 2 hours into the event, because of high temperature within the instrument cabinet, the cabinet doors were opened and cool air from the air-conditioned computer room was introduced through the control room doorway to the cabinets by portable fans and ducts. About 3 hours after the initial ventilation system failure, the control area ventilation system was returned to service and declared operable. Prior to this event, the plant had experienced numerous failures of solid state electronic components since 1981, and the licensee was aware that one of the contributing causes of the failures was the ambient temperatures to which the heat-sensitive components were exposed. Yet, only in 1985 was a comprehensive plan of corrective action to address the problem instituted.

This event was not an isolated incident as three other LWR plants also experienced similar problems during 1982-1985 (Refs. 7-10).

During a June 27, 1986, ACRS meeting, representatives of the NRC staff reported that failures of the cooling system for areas containing safetyrelated components in certain nuclear power plants could contribute significantly to the estimated CDF (Ref. 11). Some data presented in the past PRA studies on the contribution to CDF from chilled water system failures (without giving credit for either testing or operator recovery action) varied from 3.0E-04/RY to 2.0E-02/RY (Ref. 11). Based on these data, the ACRS recommended that NRC re-examine the HVAC and chilled water system problems and "take any corrective actions deemed necessary" (Ref. 12).

As a result of the ACRS recommendation, the issue was prioritized and given a HIGH priority, and PNL was engaged as the principle investigator.

During the course of the investigation, it was recognized that a set of representative plants must be identified and used as the basis for the affected CDF and public risk calculations. To do so, it was necessary to 
identify the safety-related equipment at the "set of selected plants" that exhibit similar dependency on the room cooling function. This was accomplished through reviews of design data, FSARs, LERs and other data bases and existing PRA documentation, and it was supplemented by information obtained from site visits to the representative plants. During the staff's site visits to the plants (Sequoyah, Oconee, Palo Verde, and Grand Gulf), meetings with plant personnel were held to discuss (1) design and operation of HVAC/room cooling system, (2) potential accident sequences, recovery actions, and test/maintenance requirements, and (3) information needed to determine the temperature rises following a loss of room cooling in rooms containing safetyrelated equipment and to determine the sensitivity of components to failure at elevated temperatures. Other general information requested from the plants include:

o Thermal loads in rooms containing safety-related equipment,

0 Capability of the safety equipment to withstand high temperatures,

- Operator actions that could be taken to respond to losses of room cooling,

- Description and dimension of areas containing safety-related equipment,

o Effects of external events such as fire, seismic, and flood.

Lists of system and functional dependencies were developed for the safety equipment at the representative plants. The lists helped to identify the applicable fault trees containing HVAC/room cooler failures and helped to isolate the portions of the fault trees that may contain such failures as basic events. Modifications were made to the fault trees, where needed, to incorporate HVAC/room cooler failures that were dismissed or otherwise not addressed in the existing PRAs. The modifications consisted of adding a series of events or additional branches of the fault trees to represent HVAC/room cooler failures as well as consideration of such failures as initiating events. In general, room cooling system failures are not modeled as initiating events in most PRAs. Rather, they are modeled as contributors to the safety system failures; e.g., room cooler failure may contribute to the unavailability of the ECCS furction. Although NUREG/CR-4550 (Ref. 15) addressed room cooler failures as an initiating event, because of very long room heatup time and because portable fans and ducts are available to mitigate room cooler failures, this event was not considered as a separate initiator. However, such modeling was performed in this study to verify the conclusion reached in NUREG/CR-4550 and for completeness.

The Systems Analys is and Risk Assessment (SARA) computer code and Integrated Reliability \& Risk Analys is System (IRRAS) computer code were used to quantify the contribution of room cooler failures to accident sequences that were quantified in the existing PRAs. The progression from accident sequences through consequences were extracted from NUREG-1150. Uncertainty calculations were performed after the affected cut sets were identified and quantified and the evaluation of public risks was completed. The uncertainty estimations were based on the failure distributions given in NUREG-1150 PRAs for each individual cut set element. The calculations included the $95 \%$ confidence intervals, the mean, and the median values. The uncertainty analysis provides an indication of the level of confidence in the results. 


\section{OBJECTIVE}

The purpose of the Generic Issue 143 program is to evaluate the adequacy of current designs to ensure that LWRs do not pose an unacceptable risk as a result of HVAC and chilled water systems failure. The primary objectives of the GI-143 program are to evaluate the safety of the HVAC/room cooler system in existing LWR power plants and to assess the value and impact of alternative measures for improving the overall reliability of the HVAC/room cooling function.

Probabilistic methods were used to assess the CDF, the potential reduction in risk from the modifications, and the cost effectiveness of the alternative actions. The overall objective for the resolution of $\mathrm{GI}-143$ is that the contribution from loss of HVAC/room cooling should be a small percentage of the total CDF from all causes.

For Unresolved Safety Issue (USI) A-45, "Regulatory and Backfit Analysis: Unresolved Safety Issue A-45, Shutdown Decay Heat Removal Requirements," the staff recommended that the frequency of events related to DHR failure leading to core damage should be reduced to a level around $1.0 \mathrm{E}-$ 05/RY so that the probability of such an accident in the next 30 years would be about 0.03 based on a population of around 110 LWR plants. A similar CDF objective, 1.0E-05/RY, was noted in USI A-44, "Evaluation of Station B1ackout Accidents at Nuclear Power Plants," and in GI-130, "Regulatory Analys is for the Resolution of Generic Issue 130: Essential Service Water System Failure at Multi-Unit Sites." The application of such previous objectives to GI-143 was limited to using these insights as general guidelines for the decision process described in Section 6 . Rigid application of such a quantitative objective to define an absolute requirement is discouraged. This rationale is consistent with the policy guidance in References 17, 18 and 19.

\section{ALTERNATIVE RESOLUTIONS}

The alternative resolutions considered for Generic Issue 143 are composed of several resolution elements. Each element is developed to prevent or mitigate one or more of the vulnerabilities discussed in this study. Table 3.1 summarizes the resolution elements and indicates the vulnerabilities addressed by each proposed element. A brief description of these elements is presented below.

\subsection{Description of Proposed Resolution Element}

\subsubsection{Perform Room Heatup Calculations and Thermal Fragility Analyses}

The objective of performing room heatup calculation and thermal fragility analysis is to determine the time available for operators to take corrective action, following loss of room cooling, before safety-related components fail or malfunction because of elevated temperatures. Each plant would need to perform its own analyses to accommodate plant-specific design configuration, room geometries and dimensions, construction materials, initial temperature, and heat loads. It is essential that transient thermal calculations for various rooms be performed to determine the rate of temperature rise following the loss of room cooling. Sensitivity studies should also be conducted to evaluate the effects of potential heatup 
ductwork.

\subsubsection{Review the HVAC/Room Cooler System Design}

The purpose of the system design review is to identify the important design deficiencies recognized in this study that is:

- Heavily loaded vital dc buses,

- Inadequate cooling water flow to safety-related chillers and room coolers,

- Overestimated electrical cabinet cooling capacities,

- Inadequate ventilation airflow in safety-related equipment rooins,

- Ventilation dampers and fire dampers that may compromise the HVAC function,

o Inadequate testing, maintenance, and emergency procedures,

- Actual temperatures in safety-related equipment rooms that are typically not monitored in control rooms.

The review shoild focus on the HWAC/room cooler system configuration and on the support systems needed to ensure the HVAC system function, such as service water, ac and dc power, and instrument air systems.

\subsubsection{Enhance the Preventive Maintenance and Testing Programs}

A potential generic vulnerability involving the priorities related to maintenance and testing of various HVAC and room cooling system components has been identified. Although the HVAC personnel at the plants visited in connection with this study did not specifically mention that the system is given a low priority, it was apparent from the LER review conducted in this study that numerous testing errors, maintenance errors, and preventivemaintenance- related failures have frequently occurred. There were numerous instances of failures of fan belts on room coolers and failures of essential chillers because of low refrigerant levels (Ref. 1).

The enhanced preventive maintenance, inspection, and testing programs should include improvements to maintenance procedures. Instances of failure to restore safety-related HVAC equipment to operable status following test and maintenance activities were observed in the LERs and other relevant documentation. Failure to restore the equipment to operable status is a potential cause of loss of one train of HVAC equipment and may contribute to common cause failures of redundant HVAC trains. Training of operators and maintenance personnel in the new procedures is also needed.

\subsubsection{Improve Emergency Procedures}

Based on discussions with plant operators, emergency procedures exist, at least at the plants visited in this study, to cope with the loss of HVAC/room cooling. However, there were indications in the literature reviewed that some plants do not have such emergency procedures. These plants should examine their existing operating procedures and develop adequate emergency procedures to cope with loss of HVAC/room cooling system and room temperature rises. 
An important aspect of the PRA calculations performed in this study involves operator recovery of loss of HVAC/room cooling function. When emergency procedures exist, there is a technical basis for allowing recovery actions because operators would be familiar with the necessary actions following a loss of room cooling and would also be trained in their implementation. This resolution element would benefit from the thermal analyses of the critical equipment and HVAC system identified in Item $3.1 .1 \mathrm{in}$ terms of preparing new emergency procedures or improving procedures that currently exist.

\subsubsection{Install Remote Room Temperature Monitors and Alarms}

Operators may have an indirect means of detecting a rise in room temperature (e.g., fan start/run indicators), but few plants were provided with instrumentation that allowed control room operators to monitor room temperatures. Therefore, operators may not be aware of current plant parameters that could adversely affect a decision, such as the appropriate Arw pump to start manually, or an operator may inadvertently secure a safety system from operation. In addition, the absence of real-time room temperatire monitoring could delay the implementation of backup cooling or other recovery actions.

An example of a successful implementation of this item was observed at one of the plants visited. The plant's IPE determined that the CDF associaled with loss of dc equipment room cooling was a large contributor to the total CDF. It was also determined that the equipment failure temperature would be reached rapidly, in approximately 45 minutes, following a loss of cooling to this room. In response to such an unfavorable situation, the plant staff installed a remote temperature monitoring/alarm system for tinis room that is continously displayed in the control room.

Alarm setpoints were established at temperatures well below the equipment failure temperatures. Emergency procedures were then developed to deal with a rising temperature in this room. The provisions increase the probability that operators will be able to quickly detect a failure in the room cooling system for the area and then perform emergency actions necessary to restore cooling or otherwise mitigate the effects of high temperature in the area.

It is not the intent of this proposal to install remote temperature monitoring/alarm system for every safety-related room at the plant. It is believed that operators would not benefit from such a large array of new plant information on top of the already complex control room environment. Rather, this item seeks to provide operators with prompt warning of equipment failures that could affect the operability of engineered safety feature functions that may be needed in accident conditions. Therefore, it is not necessary to install remote temperature-indicating systems in rooms that are not judged to be critical in terms of room heatup rate and the temperature fragility of safety-related equipment.

\subsubsection{Install Portable Air Cooling Equipment}

It has been observed that portable room cooling equipment intended to be used under a loss of room cooling conditions is not always located conveniently and may not be available when needed for various reasons. It is 
essential that portable room cooling equipment suc , as portable fans and ductwork be available when needed in emergency situations. Plants may benefit from having portable room cooling equipment available at all times in or near the critical rooms identified in Element 3.1.1.

\subsubsection{Install Thermal Barriers Between Heat-Producing Components and Thermal- Sensitive Components}

One of the findings from this study was that emergency diesel generator enclosures in which the control equipment was located in a separate compartment from the diesel engine had significantly more time for recovery of emergency diesel generator room yentilation or restoration activities than those in which the diesel engine and emergency diesel generator control equipment is located in the same room. Since the diesel engine is not particularly vulnerable to room temperature excursions, protecting the emergency diesel generator control equipment could increase the time available to implement recovery actions (the probability of recovery from an emergency diesel generator ventilation system failure was assumed to be zero in this study). This would increase the likelihood the recovery of emergency diesel generator ventilation functions could be completed before the emergency diesel generator fails because of control system overheating. The thermal barrier should be designed to protect the emergency diesel generator control system from the diesel engine for a sufficient length of time to ensure that offsile power or other onsite power sources can be restored.

\subsubsection{Install a Permanent Backup Cooling System}

HVAC systems are typically designed to provide each train of safety-related equipment with its own train of HVAC/room cooling equipment. For example, some plants are provided with two separate residual heat removal (RHR) pump trains. A single room cooler is provided for each RHR train that receives motive and control power from the same train of equipment providing motive and control power for the RHR pumps. That is, each RHR pump is conled by an individual room cooler. Failure of either room cooler could lead to loss of the RHR pump served by that room cooler. Backup room cooling capabilities are generally not provided in these cases. This proposal involves installation of redundant room cooling systems in "critical" areas as identified in item 1. The room cooling equipment could be powered from the other equipment train or it could be $d c$-powered and thus remove any dependence on motive power from the potentially affected equipment train. Such a system has been installed in the auxiliary feedwater pump room of a PWR plant. The backup system could be actuated either automatically or manually, depending upon the type of system needed.

\subsubsection{Test Electrical Cabinet Temperatures}

Inadequate cooling within the electrical cabinets was identified as a generic vulnerability in this study. The current design basis temperatures for electrical components are based on a maximum internal cabinet temperature that is obtained by adding $20^{\circ} \mathrm{F}$ to the maximum ambient temperature. If the control room maximum temperature is set at $104^{\circ} \mathrm{F}$, the components in control cabinents are designed to withstand $124^{\circ} \mathrm{F}$ internal cabinet temperatures. In 
some cases, this has been shown to be an inadequate basis for establishing temperature qualifications for electrical components within a cabinet.

The proposed tests would involve placing of thermocouples or other temperature measuring devices at selected locations inside the cabinet, powering up the cabinet, and then measuring the temperatures. Room ambient temperatures would also be measured so that the temperature difference between the cabinet and the surrounding room area can be determined. The information gained from this test program would be used to identify cabinets that require additional cooling capabilities, to recommend potential cabinet modifications to enhance airflow (e.g., eliminating dead spots inside the cabinet), aid to identify critical cabinets that may be more susceptible to overheating than others.

\subsubsection{Initiate an Airflow Test Program}

This study identified another vulnerabi?ity in potentially inadequate airflow balance in safety-related equipment areas, particularly those containing arrays of cabinets such as switchgear rooms. Since these cabinets are primarily cooled by natural convection, airflow around the cabinets is important for dissipating heat. Dead spots or pockets with little or no airflow can reduce the convective heat transfer to the point at which less heat is being dissipated than is being generated within the cabinets.

The proposed test program is to identify and eliminate airflow problems that may cause overheating in cabinets. At least one utility, in responding to a previous LER, has identified airflow difficulties through a program of measurements and has made appropriate adjustment to the airflow path and flow rate. Deficiencies identified through this program may be resolved by changing the flow balances, installing deflectors to direct airflow to appropriate locations, rearranging cabinets to promote natural convection, or installing additional equipment such as fans and ductwork.

\subsection{Proposed Alternative Resolutions}

Four alternatives were developed within the range of possible costs and benefits for the resolution of GI-143. The first alternative is to take no action. The second alternative is the minimum improvement alternative, which combines plant evaluation with procedural and maintenance improvements to prevent or mitigate potential losses of room cooling. The third alternative combines the elements of Alternative 2 with relatively minor hardware changes designed to improve detection and recovery capabilities. The fourth alternative would provide the maximum improvement in HVAC/room cooling reliability and combine the elements of Alternative 3 with additional testing programs and hardware changes. Each alternative addresses, to some extent, all the vulnerabilities identified in this study. The alternatives are summarized in Table 3.2 and described below.

\subsubsection{Alternative 1 - No Action}

With this alternative, there would be no new regulatory requirements. Consistent with existing regulations, this alternative does not preclude a licensee or an applicant for an operating license from proposing to the NRC 
staff any design changes intended to enhance the reliability or operability of the HVAC/room cooling system or its components on a plant-specific basis.

\subsubsection{Alternative 2 - Perform Fragility Analysis, System Design Review, Maintenance and Testing Program, and Improve Emergency Procedures}

This alternative is the minimum-cost, minimum-benefit proposal. It consists of resolution Elements 3.1.1 through 3.1.4. Elements 3.1.1 and 3.1.2 are studies designed to define, evaluate, and prioritize, on a plant-specific basis, the potential vulnerabilities to loss of HVAC and room cooling functions. The results of the studies would be used to identify specific rooms and areas susceptible to rapid heatup rates, identify thermal-sensitive components in these room or areas, determine possible mechanisms that could cause a loss of cooling in these rooms or areas, and prioritize the areas of most concern to plant safety. These studies can also form the bas is for suggesting means to improve the reliability of HVAC/room cooler systems and suggesting the most sensitive areas for improved hardware, maintenance, or emergency procedures.

\subsubsection{Alternative 3 - Combine Alternative 2 with Installing Remote} Temperature Monitors or Alarms and Portable Air Cooling Equipment

Alternative 3 includes the first six elements listed above. It involves installation of remote temperature-monitoring systems in the plant's most vulnerable areas (i.e., areas that would heat up rapidly following a loss of room cooling and that contain temperature-sensitive equipment). The remote temperature-monitoring systems should be designed to continuously measure room temperature, and read out in the control room, and they would be designed to alarm when the temperature rises to the equipment operating safety limit. A monitoring system has been installed in at least one plant to continuously monitor room temperatures in its dc equipment rooms. Alarm set points were established at a temperature below which the dc equipment would not be susceptible to failure and would allow operators sufficient time to implement temporary cooling, if needed.

This alternative also involves purchasing and having available portable cooling equipment to improve the likelihood of successful operator recovery actions. A satisfactory example of a portable system would be one consisting of portable fans and flexible ductwork, located in the most vulnerable areas. Because many of the core damage accident scenarios examined in this study are initiated by a loss of offsite power or can evolve into a station blackout situation, it may be prudent to provide portable dc-powered fans.

3.2.4 Alternative 4 - Combine Alternative 3 with Installation of Thermal Barriers, Permanent Backup Cooling System, Cabinet Temperature Test, and Airflow Test Program

This alternative is the highest cost, highest benefit proposal examined in this study. It involves all the resolution elements described in this section. A backup room cooling system would be installed to remove heat from the engineered safety feature pump rooms and dc equipment rooms, switchgear rooms, and control rooms. This is a more costly and more effective method of improving room cooling reliability than installation of portable room cooling 
equipment. One of the plants visited in this study was provided with a backup dc-powered room cooler in the turbine driven auxiliary feedwater pump room.

One of the findings in this study shown that when emergency diesel generator control equipment was located in a separate room from the diesel engine, there was significantly more time available to effect emergency diesel generator room ventilation recovery or restoration activities than where the diesel engine and emergency diesel generator control equipment are located in the same room. There is no practical recovery from loss of the emergency diesel generator ventilation system because the time available for operator action is too short (the probability of recovery from an emergency diesel generator ventilation system failure was assumed to be zero). Since the diesel engine is not particularly sensitive to room temperature excursions, protecting the emergency diesel generator control equipment from the heat source, e.g., the diesel generator, could increase the time needed to implement recovery actions or return the emergency diesel generator ventilation system to operable status. One method of insulating the emergency diesel generator control equipment from the diesel engine is to provide a thermal barrier between the generator and the controls, thus effectively reducing the room heatup rate in the vicinity of the emergency diesel generator control equipment. This would increase the likelihood that recovery of emergency diesel generator ventilation functions could be completed before the emergency diesel generator fails because of control system overheating.

Actual temperatures within the electrical cabinets should be measured. The purpose of having these measurements is to determine the actual difference between the cabinet internal temperatures and the room ambient temperatures. The test results will provide insights on whether any specific corrective actions are needed to improve the heat rejection capability of potentially vulnerable cabinets. Remedies for overheated cabinets include installing portable or permanent backup cooling equipment to cope with potential overheating situations or replacing existing cabinet components with those that are less sensitive to elevated temperature.

The objective of the airflow test program is to identify areas that are not receiving sufficient airflow to remove heat generated in the electrical cabinets. If dead spots are detected, airflow deflectors may be installed to redirect airflow path, or additional fans may be installed to enhance air circulation or modify airflow balances. 
Table 3.1 Matrix of Vulnerabilities vs. Resolution Elements

\begin{tabular}{|c|c|c|c|c|c|c|c|c|c|c|}
\hline \multirow[b]{2}{*}{ Vulnerability } & \multicolumn{10}{|c|}{ Resolution Element Addressing Specific Vulnerability } \\
\hline & 1 & 2 & 3 & 4 & 5 & 6 & 7 & 8 & 9 & 10 \\
\hline 1. Spuricus actuation of control room components inside cabinets & $x$ & & & & $x$ & $x$ & $x$ & & & $x$ \\
\hline 2. Temperature-sensitivity of dc equipment (inverter, battery charger) & $x$ & & & & $x$ & $x$ & $x$ & & & \\
\hline $\begin{array}{l}\text { 3. Loss of emergency diesel generator ventilation system rapidly } \\
\text { fails emergency diesel generator control equipment }\end{array}$ & $x$ & & & & & $x$ & $x$ & $x$ & & \\
\hline 4. Installation errors disable HVAC-related water systems & & $x$ & & & & & & & & \\
\hline 5. Inadequate test/maintenance procedures & & & $x$ & & & & & & & \\
\hline 6. Inadequate PM Program for HVAC/room cool ing equipment & & & $\mathbf{x}$ & & & & & & & \\
\hline 7. Failed/malfunctioning ventilation and fire dampers & $x$ & $x$ & $x$ & & $x$ & $x$ & $x$ & & & \\
\hline 8. Design errors lead to inadequate airflow & $x$ & $x$ & & & $x$ & & & & & $x$ \\
\hline 9. Electrical cabinets overheat because of fan failures & $x$ & & $x$ & $x$ & & $x$ & $x$ & & $x$ & $x$ \\
\hline 10. Electrical cabinet heat rejection capabilities overestimated & $x$ & $x$ & & & & & & & $x$ & $x$ \\
\hline 11. Actual room temperatures not monitored in control rooms & & $x$ & & $x$ & $x$ & & & & & \\
\hline 12. Essential chiller design not optimized & & $x$ & & & & & & & & \\
\hline 13. Inadequate separation between electrical cables & & $x$ & & & & & & & & \\
\hline 14. Heavily-loaded vital dc buses & & $x$ & & & & & & & & \\
\hline 15. Inadequate emergency procedures to cope with loss of room cooling & & & & $x$ & $x$ & & & & & \\
\hline 16. Small room vs. large room & $x$ & $x$ & & & & $x$ & $x$ & & & \\
\hline 17. Fires and $f$ loods dominated affected CDF because of external events & $x$ & $x$ & & $x$ & & $x$ & $x$ & & & \\
\hline
\end{tabular}

17. Fires and floods dominated affected CDF because of external events

follows. See text for complete descriptions of resolution elements. 1. Perform room heatup

Resolution calculations and thermal fragitity analyses. 2. Ponitors/Alarms. 6. Install Portable Air Cool ing Equipment. 7. Install Permanent Procedures. 5. Install Remote Room Temperature Monitors/Alarms. Backup Room Cooling Systems. 8 . I0. Airflow Test Program. 
Table 3.2 Summary of Alternative Resolutions to GI-143

\begin{tabular}{|c|c|}
\hline Alternative & Resolution Elemants \\
\hline 1 & No Action \\
\hline 2 & $\begin{array}{l}\text { 1. P rform room heatup calculations and thermal } \\
\text { fragility analyses } \\
\text { 2. Perform design review } \\
\text { 3. Enhanced preventive maintenance and testing } \\
\text { program } \\
\text { 4. Improve emergency procedures }\end{array}$ \\
\hline 3 & $\begin{array}{l}\text { 1. Perform room heatup calculations and thermal } \\
\text { fragility analyses } \\
\text { 2. Perform design review } \\
\text { 3. Enhanced preventive maintenance and testing } \\
\text { program } \\
\text { 4. Improve emergency procedures } \\
\text { 5. Install remote temperature monitors with alarms } \\
\text { 6. Install portable room cooling equipment }\end{array}$ \\
\hline 4 & $\begin{array}{l}\text { 1. Perform room heatup calculations and thermal } \\
\text { fragility analyses } \\
\text { 2. Perform design review } \\
\text { 3. Enhanced preventive maintenance and testing } \\
\text { program } \\
\text { 4. Improve emergency procedures } \\
\text { 5. Install remote temperature monitors and alarms } \\
\text { 6. Install portable room cos'ing equipment } \\
\text { 7. Install permanent backup room cooling systems } \\
\text { 8. Install thermal barriels between heat-producing } \\
\text { components and thermally sensitive components } \\
\text { thermally sensitive components } \\
\text { 9. Test electrical cabinets } \\
\text { 10. Institute an airflow test program }\end{array}$ \\
\hline
\end{tabular}




\section{TECHNICAL FINDINGS}

Pacific Northwest Laboratories' evaluation of the HVAC/room cooling system reliability analysis consisted of (1) identifying engineered safety feature (ESF) dependencies on HVAC or room coolers, (2) establishing a list of representative plants, (3) developing a list of cut sets involving room cooler failures, (4) identifying and modifying affected accident sequences, and (5) quantifying affected CDF and public risks. The following sections provide a brief discussion of these areas.

\subsection{Identify the Vulnerabilities of Safety-Related Systems}

The objective of this effort is to develop a data base of HVAC and chilled water system failures to be used as a technical basis for evaluating of the system's reliability. The data base and failure history established the basis for the failure frequencies of HVAC and the chilled water system. The failure frequencies were used to assess the vulnerabilities of plant equipment and, ultimately, as the basis for developing and evaluating the proposed resolution for this safety issue. The data base and evaluations were mainly focused on the following safety functions:

- Reactivity control

- Core cooling and heat removal

- Reactor coolant system integrity

o Containment cooling and isolation

- Radioactivity control

Examples of systems performing such safety functions are:

- Reactor protection system and control (including instrumentation and control within the control room)

- Emergency core cooling system

- Auxiliary feedwater system

- Decay heat removal system

- Containment cooling or isolation

- Essential service water and component cooling water system

o Onsite emergency electric power sources and distribution system

- Instrument air system

\subsubsection{Review and Evaluation of Open Literature}

To develop the data base, a computerized literature search was performed using PNL's Technical Library Services. The search included several computerized document retrieval systems, including the Department of Energy's (DOE) Technical Information Center, the National Technical Information System (NTIS), Energy Research Abstracts (ERA), and Nuclear Computerized Library for Assessing Reactor Reliability (NUCLARR). The computerized search included international as well as U.S. sources. Records obtained from these retrieval systems were reviewed according to the following categories: 
1. HVAC/chilled water system reliability

2. Reliability of components in rooms cooled by HVAC or chilled water systems

3. Development of proposed resolution

4. Definition or quantification of potential accident sequences

5. Environmental limitations of safety-related components

6. Environmental conditions in rooms containing safety-related equipment

7. Operator recovery actions and timing

8. Basic cost data

9. Occupational exposure data

The search was performed using key words, including "HVAC," "room coolers," and "chilled water." Any record that contained these key words would be retrieved and reviewed accordingly. Records considered to be redundant or irrelevant to this safety issue were eliminated. The results of the examination of documents reviewed in this study relative to the applicable categories are presented in Tables 4.1 and 4.2.

\subsubsection{Review of Licensee Event Report (LER)}

The Nuclear Documents Systems/Advance Design (NUDOCS/AD) computerized data base system was used to search for LERs involving the HVAC/room cooler failures. A total of 1115 records were identified (Ref. 1). Preliminary review of these records indicated that there were many duplicate records and records that did not represent a failure of HVAC or room coolers to remove heat from safety-related areas. As a result, additional searches and reviews were performed to identify actual components or system failures relevant to this investigation. Irrelevant records and duplicate records were eliminated through the detailed review and examination. The remaining LERs were examined to identify the causes of room cooler failures. Some of the causes of failures are:

- Frayed beits on room cooler fans

- Pitting or burning of contacts on room cooler or fan motor center contactor

- Seal failures on recirculation dampers

- Low refrigerant level in chiller

- Inadequate ac power or power tripped by personnel

- Faults on dc distribution panels

- ESW flow blocked by debris or inadequate because of design errors

- Inadequate thermal overload protection devices

- Procedural errors result, for example, in inoperable essential chilled water pumps

- Inadequate airflow rate 
Table 4.1 Number of Records Reviewed in Each Applicability Category

\begin{tabular}{|c|c|c|}
\hline $\begin{array}{l}\text { Applicability } \\
\text { Category }\end{array}$ & Applicability Category Description & $\begin{array}{c}\text { Number of } \\
\text { Documents }\end{array}$ \\
\hline 1 & HVAC/chilled water system reliability & 15 \\
\hline 2 & $\begin{array}{l}\text { Reliability of components in rooms } \\
\text { cooled by HVAC/chilled water systems }\end{array}$ & 12 \\
\hline 3 & $\begin{array}{l}\text { Development of proposed resolution } \\
\text { Definition or quantification of } \\
\text { potential accident sequences }\end{array}$ & 16 \\
\hline 4 & $\begin{array}{l}\text { Environmental limitations of } \\
\text { safety-related components }\end{array}$ & 10 \\
\hline 5 & $\begin{array}{l}\text { Environmental conditions in rooms } \\
\text { containing safety-related equipment }\end{array}$ & 3 \\
\hline 6 & Operator recovery actions and timing & 6 \\
\hline 8 & Basic cost data & 1 \\
\hline 9 & Occupational exposure data & 11 \\
\hline
\end{tabular}


Table 4.2 HVAC and Room Cooler Failure Data from NUCLARR

\begin{tabular}{|c|c|c|}
\hline Component & Failure Mode & Failure Rate \\
\hline \multirow[t]{2}{*}{$\begin{array}{l}\text { Air Conditioning Units } \\
\text { or Chillers }\end{array}$} & Fails to run & $\begin{array}{l}1.5 E-5 / h r \\
9.7 E-6 / h r\end{array}$ \\
\hline & Fails to start & 1.3E-2/demand \\
\hline Dampers & Fails to operate & 2.8E-3/demand \\
\hline \multirow[t]{2}{*}{ Fan Cooler Units } & Fails to run & $\begin{array}{l}1.5 \mathrm{E}-6 / \mathrm{hr} \\
2.9 \mathrm{E}-5 / \mathrm{hr}\end{array}$ \\
\hline & Fails to start & $\begin{array}{l}\text { 1.9E-3/demand } \\
6.4 \mathrm{E}-3 / \text { demand }\end{array}$ \\
\hline \multirow[t]{2}{*}{ Ventilating Fans } & Fails to run & $9.0 \mathrm{E}-7 / \mathrm{hr}$ \\
\hline & Fails to start & 4.6E-3/demand \\
\hline Heat Exchangers & Fails to run & $\begin{array}{l}2.8 E-6 / h r \\
2.8 E-6 / h r \\
3.2 E-6 / h r \\
3.2 E-6 / h r \\
1.0 E-6 / h r\end{array}$ \\
\hline
\end{tabular}


Potential common cause failures that could result in simultaneous disabling or failure of more than one entire cooling train or more than one room cooler were also identified. These fallures may be categorized as:

- Design errors

- Failure and blockage of essential service water

- Operator error

- Equipment failure (other than essential service water; e.g., failure of power sources or failure of the essential chiller)

Tables 4.3, 4.4, and 4.5 present the results of LER failures involving room coolers and HVAC systems from 1980 through 1991.

The information in the preceding tables and figures was used to develop reliability and other data for the HVAC and room cooler systems. These data are presented in Table 4.8. As can be seen, the failure rates range from about $6 E-6 / \mathrm{hr}$ for failure of one train of the control room HVAC system to about $2 \mathrm{E}-7 / \mathrm{hr}$ for control rod drive power supply room coolers. These appear to be within the ranges of component failure rates indicated in the NUCLARR data base.

\subsection{Establish a List of Representative Plants}

In the process of 1 isting the representative plants, it is necessary to identify the degree of "typicality" exhibited by the various room cooling system designs at various LWR nuclear power plants. The following parameters were evaluated.

- Plant age

- System design characteristics, e.g., large centralized HVAC/room cooling systems vs. a large number of smaller systems

- Cross-connecting capability between units at multi-unit sites

- Differences that might arise from reactor types, i.e., PWR vs. BWR or among reactor vendors

- Difference in room cooling system designs that are attributed to the source of cooling water, i.e., fresh water vs. marine vs. estuarine service water sources

To develop insights on the items listed above, the Final Safety Analysis Reports (FSARs) and design information from a number of nuclear power plants were reviewed. Based on the plant design reviews, it was determined that there are no "generic" HVAC or room cooling system designs that could represent the entire population of plants. Each plant seems to have individual design features that often are relatively subtle. For example, one plant located the component cooling water pumps in a large open area along with other safety-related pumps. Room cooling in this area was provided by a 
Table 4.3 LER Data for Room Cooler and HVAC Failures Designated as "Other"

\begin{tabular}{|c|c|c|c|c|c|c|c|c|c|c|c|c|c|c|c|c|}
\hline \multirow[b]{2}{*}{ Roonvarea } & \multirow[b]{2}{*}{1980} & \multirow[b]{2}{*}{1981} & \multirow[b]{2}{*}{1982} & \multirow[b]{2}{*}{1963} & \multirow[b]{2}{*}{1984} & \multirow[b]{2}{*}{1985} & \multirow[b]{2}{*}{1986} & \multirow[b]{2}{*}{1987} & \multirow[b]{2}{*}{1980} & \multirow[b]{2}{*}{1989} & \multirow[b]{2}{*}{1990} & \multirow[b]{2}{*}{1991} & \multicolumn{2}{|c|}{1980 to 1991 DATA } & \multicolumn{2}{|c|}{1985 to 1991 DATA } \\
\hline & & & & & & & & & & & & & TOTAL & AVERAGE & TOTAL & AVERAGE \\
\hline Emergency Gas Treatment System Room & & & 1 & 1 & & 1 & & 1 & & & 1 & & 5 & 0.42 & 3 & 0.43 \\
\hline Control Rod Drive Power Supply Room & & & & & & 1 & & & & & & & 1 & 0.08 & 1 & 0.14 \\
\hline Reactor Building HVAC & & & & & & 2 & & & & & & & 2 & 0.17 & 2 & 0.29 \\
\hline Centrifugal Charging Pump Room & & & & & & 1 & & 2 & & & 1 & 1 & 5 & 0.42 & 5 & 0.71 \\
\hline Contaiment Coolers & & & & & & 1 & & & & & & & 1 & 0.08 & 1 & 0.14 \\
\hline Contaiment Spray Pump Room & & & & & & 1 & & 2 & & 2 & 1 & 1 & 7 & 0.58 & 7 & 1.00 \\
\hline Component cool ing Water Punp Room & & & & & & & & 1 & & 1 & 1 & & 3 & 0.25 & 3 & 0.43 \\
\hline Vital AC Inverter Room & & & & & & & & 2 & & 1 & 1 & & 4 & 0.33 & 4 & 0.57 \\
\hline Battery Room & & & & & & & & 3 & & & & $\mathbf{1}$ & 6 & 0.33 & 4 & 0.57 \\
\hline Essential Chiller & & & & & & & & 3 & 2 & 3 & 1 & & 9 & 0.75 & 9 & 1.29 \\
\hline Essential Service Mater Pump Room & & & & & & & & 2 & 2 & & 2 & 1 & 7 & 0.58 & 7 & 1.00 \\
\hline Electrical Penetration Rooms & & & & & & & & 3 & & & & & 3 & 0.25 & 3 & 0.43 \\
\hline Representative Heat Exchenger Room & & & & & & & 1 & 1 & & & 1 & & 3 & 0.25 & 3 & 0.43 \\
\hline Reactor water Cleanup Pump Room & & & & & & & & 3 & 2 & & 1 & 2 & 8 & 0.67 & 8 & 1.14 \\
\hline Auxiliary feedwater Pump Room & & & & & & & & 3 & 2 & & 1 & 2 & 8 & 0.67 & 8 & 1.14 \\
\hline
\end{tabular}




\section{Table 4.4 Common Cause Failure Data from LER Reviews of HVAC and Room Cooler Failures}

\begin{tabular}{|c|c|c|c|c|c|c|c|c|c|c|c|c|c|c|c|c|}
\hline \multirow[b]{2}{*}{ Potential Common Cause Failure } & \multirow[b]{2}{*}{1980} & \multirow[b]{2}{*}{1981} & \multirow[b]{2}{*}{1982} & \multirow[b]{2}{*}{1983} & \multirow[b]{2}{*}{1984} & \multirow[b]{2}{*}{1985} & \multirow[b]{2}{*}{1986} & \multirow[b]{2}{*}{1987} & \multirow[b]{2}{*}{1988} & \multirow[b]{2}{*}{1989} & \multirow[b]{2}{*}{1990} & \multirow[b]{2}{*}{1991} & \multicolumn{2}{|c|}{1980 to 1991 DATA } & \multicolumn{2}{|c|}{1985 to 1991 DATA } \\
\hline & & & & & & & & & & & & & TOTAL & AVERAGE & TOTAL & AVERAGE \\
\hline Design Errors & & & 1 & & & 1 & 6 & 6 & 3 & 8 & 4 & 2 & 31 & 2.58 & 30 & 4.29 \\
\hline ESH Blockage & 1 & & 1 & & & 4 & 1 & 3 & 3 & 1 & 2 & 1 & 17 & 1.42 & 15 & 2.14 \\
\hline Personnel Error & & & & & & & & 2 & 2 & & & & 4 & 0.33 & 4 & 0.57 \\
\hline Equipment Failure & & 1 & & 1 & & & & & 1 & 1 & & 1 & 5 & 0.42 & 3 & 0.43 \\
\hline TOTAL & 1 & 1 & 2 & 1 & 0 & 5 & 7 & 11 & 9 & 10 & 6 & 4 & 57 & 4.75 & 52 & 7.43 \\
\hline
\end{tabular}


Table 4.5 HVAC or Room Cooler Malfunction Frequencies for Each Nuclear Power Plant (1980 to 1992)

\begin{tabular}{|c|c|c|c|c|}
\hline & \begin{tabular}{|l|} 
Year \\
Entered \\
Commercial \\
Operation
\end{tabular} & $\begin{array}{l}\text { Yrs. Comm. } \\
\text { Operation } \\
\text { Since } 1980\end{array}$ & $\begin{array}{c}\text { Number of } \\
\text { Malfunctions Since } \\
1980\end{array}$ & $\begin{array}{l}\text { Annual } \\
\text { Frequency }\end{array}$ \\
\hline \multicolumn{5}{|l|}{ Westinghouse PWRs } \\
\hline $\begin{array}{l}\text { Beaver Valley } 1 \\
\text { Beaver Valley } 2 \\
\text { Ginna } \\
\text { Haddam Neck } \\
\text { Indian Pt. 2 } \\
\text { Indian Pt. 3 } \\
\text { Salem 1 } \\
\text { Salem 2 }\end{array}$ & $\begin{array}{l}76 \\
87 \\
70 \\
67 \\
74 \\
76 \\
77 \\
81\end{array}$ & $\begin{array}{r}12 \\
5 \\
12 \\
12 \\
12 \\
12 \\
12 \\
11\end{array}$ & $\begin{array}{l}0 \\
0 \\
0 \\
0 \\
1 \\
0 \\
1 \\
2\end{array}$ & $\begin{array}{l}0.000 \\
0.000 \\
0.000 \\
0.000 \\
0.083 \\
0.000 \\
0.083 \\
0.182\end{array}$ \\
\hline $\begin{array}{l}\text { Yankee Rowe } \\
\text { Millstone } 3 \\
\text { North Anna } 1 \\
\text { North Anna } 2 \\
\text { Catawba } 1 \\
\text { Catawba } 2 \\
\text { Farley } 1 \\
\text { Farley 2 } \\
\text { Hannic } 1\end{array}$ & $\begin{array}{l}60 \\
86 \\
78 \\
80 \\
85 \\
85 \\
77 \\
81\end{array}$ & $\begin{array}{r}12 \\
6 \\
12 \\
12 \\
7 \\
7 \\
12 \\
11\end{array}$ & $\begin{array}{l}0 \\
0 \\
0 \\
0 \\
4 \\
0 \\
2 \\
1\end{array}$ & $\begin{array}{l}0.000 \\
0.000 \\
0.000 \\
0.000 \\
0.571 \\
0.000 \\
0.167 \\
0.091\end{array}$ \\
\hline $\begin{array}{l}\text { McGuire 1 } \\
\text { McGuire 2 } \\
\text { Robinson 2 } \\
\text { Sequoyah 1 } \\
\text { Sequoyah 2 } \\
\text { Summer } \\
\text { Surry 1 } \\
\text { Surry 2 } \\
\text { Turkey Pt. 3 } \\
\text { Turkey Pt. 4 } \\
\text { Watts Bar 1 }\end{array}$ & $\begin{array}{l}81 \\
84 \\
71 \\
81 \\
82 \\
84 \\
72 \\
73 \\
72 \\
73\end{array}$ & $\begin{array}{r}11 \\
8 \\
12 \\
11 \\
10 \\
8 \\
12 \\
12 \\
12 \\
12\end{array}$ & $\begin{array}{l}3 \\
0 \\
2 \\
9 \\
0 \\
2 \\
0 \\
0 \\
1 \\
0\end{array}$ & $\begin{array}{l}0.273 \\
0.000 \\
0.167 \\
0.818 \\
0.000 \\
0.250 \\
0.000 \\
0.000 \\
0.083 \\
0.000\end{array}$ \\
\hline $\begin{array}{l}\text { Watts Bar 2 } \\
\text { Vogtle 1 } \\
\text { Vogtle 2 } \\
\text { Byron 1 } \\
\text { Byron 2 } \\
\text { Cook 1 } \\
\text { Cook 2 } \\
\text { Cal laway } \\
\text { Kewaunee }\end{array}$ & $\begin{array}{l}87 \\
89 \\
85 \\
87 \\
75 \\
78 \\
84 \\
74\end{array}$ & $\begin{array}{r}5 \\
3 \\
7 \\
5 \\
12 \\
12 \\
8 \\
12 \\
12\end{array}$ & $\begin{array}{l}2 \\
1 \\
1 \\
0 \\
0 \\
1 \\
5 \\
0\end{array}$ & $\begin{array}{l}0.400 \\
0.333 \\
0.143 \\
0.000 \\
0.000 \\
0.083 \\
0.625 \\
0.000\end{array}$ \\
\hline
\end{tabular}


Table 4.5 Continued

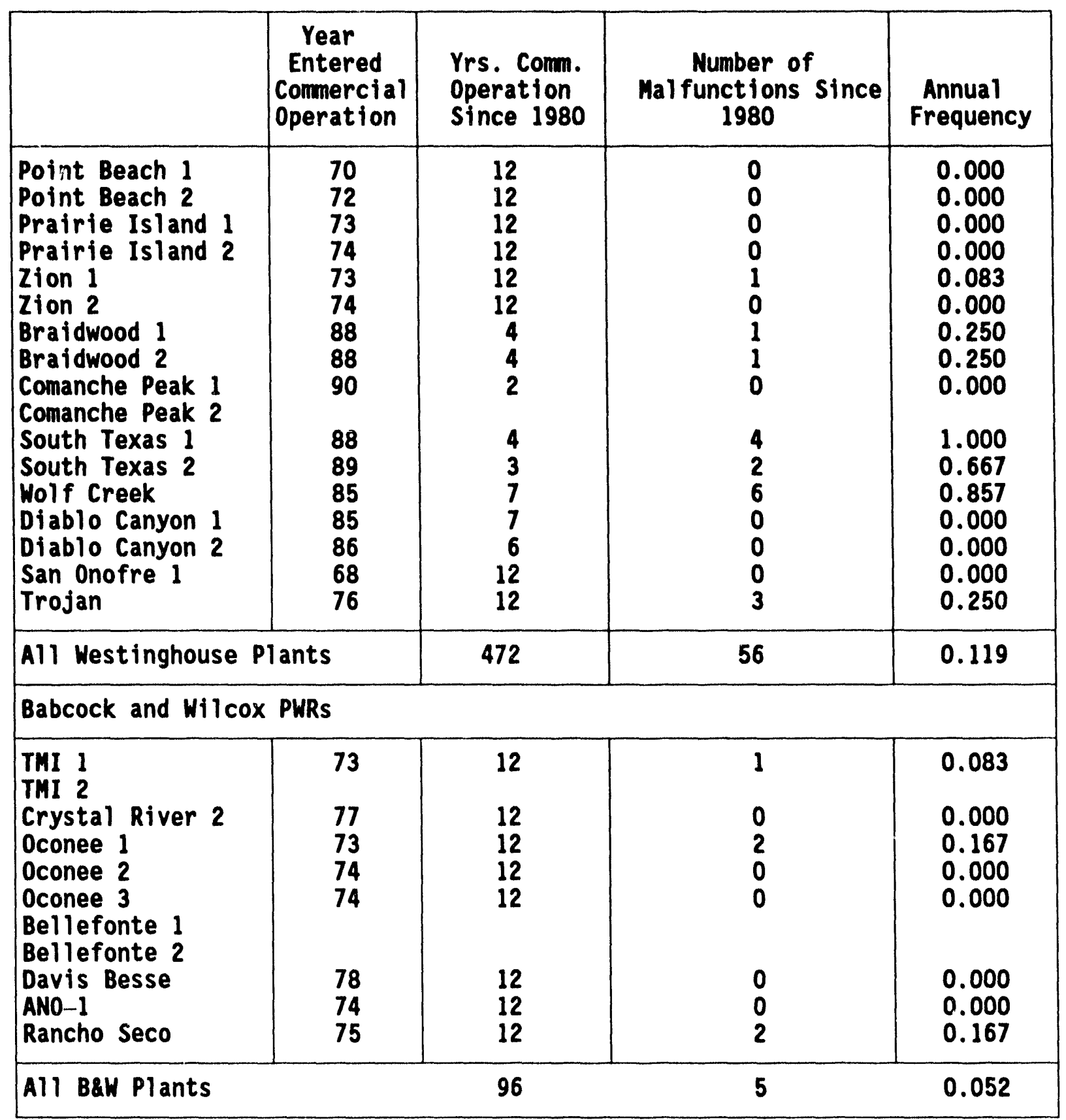


Table 4.5 Continued

\begin{tabular}{|c|c|c|c|c|}
\hline & \begin{tabular}{|c|} 
Year \\
Entered \\
Commercial \\
Operation
\end{tabular} & $\begin{array}{l}\text { Yrs. Comm. } \\
\text { Operation } \\
\text { Since } 1980\end{array}$ & $\begin{array}{c}\text { Number of } \\
\text { Mal functions Since } \\
1980\end{array}$ & $\begin{array}{l}\text { Annual } \\
\text { Frequency }\end{array}$ \\
\hline \multicolumn{5}{|c|}{ Combustion Engineering PWRs } \\
\hline $\begin{array}{l}\text { Calvert Cliffs } 1 \\
\text { Calvert Cliffs } 2 \\
\text { Maine Yankee } \\
\text { Millstone 2 } \\
\text { St. Lucie 1 } \\
\text { St. Lucie 2 } \\
\text { Palisades } \\
\text { ANO-2 } \\
\text { Fort Calhoun } \\
\text { Waterford } \\
\text { Palo Verde 1 } \\
\text { Palo Verde 2 } \\
\text { Palo Verde 3 } \\
\text { San Onofre 2 } \\
\text { San Onofre 3 }\end{array}$ & $\begin{array}{l}75 \\
77 \\
72 \\
75 \\
76 \\
83 \\
71 \\
80 \\
74 \\
85 \\
86 \\
86 \\
88 \\
83 \\
84\end{array}$ & $\begin{array}{r}12 \\
12 \\
12 \\
12 \\
12 \\
9 \\
12 \\
12 \\
12 \\
7 \\
6 \\
6 \\
4 \\
9 \\
8\end{array}$ & $\begin{array}{l}1 \\
2 \\
0 \\
0 \\
0 \\
0 \\
5 \\
1 \\
0 \\
2 \\
3 \\
1 \\
0 \\
0 \\
0\end{array}$ & $\begin{array}{l}0.083 \\
0.167 \\
0.000 \\
0.000 \\
0.000 \\
0.000 \\
0.417 \\
0.083 \\
0.000 \\
0.286 \\
0.500 \\
0.167 \\
0.000 \\
0.000 \\
0.000\end{array}$ \\
\hline \multicolumn{2}{|l|}{ All CE Plants } & 145 & 15 & 0.103 \\
\hline \multicolumn{5}{|c|}{ General Electric BWRs } \\
\hline $\begin{array}{l}\text { Hope Creek 1 } \\
\text { Fitzpatrick } \\
\text { Limerick 1 } \\
\text { Limerick 2 } \\
\text { Millstone 1 } \\
\text { Nine Mile Point 1 } \\
\text { Nine Mile Point } 2 \\
\text { Oyster Creek } \\
\text { Peach Bottom 2 } \\
\text { Peach Bottom 3 } \\
\text { Pilgrim } \\
\text { Shoreham } \\
\text { Susquehanna 1 } \\
\text { Susquehanna 2 } \\
\text { Vermont Yankee }\end{array}$ & $\begin{array}{l}86 \\
75 \\
86 \\
90 \\
71 \\
59 \\
88 \\
69 \\
74 \\
74 \\
72 \\
\\
83 \\
85 \\
72\end{array}$ & $\begin{array}{r}6 \\
12 \\
6 \\
2 \\
12 \\
12 \\
4 \\
12 \\
12 \\
12 \\
12 \\
9 \\
9 \\
12\end{array}$ & $\begin{array}{l}1 \\
1 \\
2 \\
0 \\
0 \\
1 \\
0 \\
0 \\
5 \\
3 \\
0 \\
1 \\
1 \\
3 \\
0\end{array}$ & $\begin{array}{l}0.167 \\
0.083 \\
0.333 \\
0.000 \\
0.000 \\
0.083 \\
0.000 \\
0.000 \\
0.417 \\
0.250 \\
0.000 \\
0.111 \\
0.429 \\
0.000\end{array}$ \\
\hline
\end{tabular}


Iable 4.5 Continued

\begin{tabular}{|c|c|c|c|c|}
\hline & \begin{tabular}{|c|} 
Year \\
Entered \\
Commercial \\
Operation
\end{tabular} & $\begin{array}{l}\text { Yrs. Comm. } \\
\text { Operation } \\
\text { Since } 1980\end{array}$ & $\begin{array}{c}\text { Number of } \\
\text { Mal functions Since } \\
1980\end{array}$ & $\begin{array}{c}\text { Annual } \\
\text { Frequency }\end{array}$ \\
\hline \multirow{5}{*}{$\begin{array}{l}\text { Browns Ferry } 1 \\
\text { Browns Ferry } 2 \\
\text { Browns Ferry } 3 \\
\text { Brunswick 1 } \\
\text { Brunswick 2 } \\
\text { Grand Gulf } 1 \\
\text { Grand Gulf } 2 \\
\text { Hatch 1 } \\
\text { Hatch 2 } \\
\text { Arnold } \\
\text { Big Rock Verde } \\
\text { Clinton 1 } \\
\text { Dresden 1 } \\
\text { Dresden 2 } \\
\text { Dresden 3 } \\
\text { Fermi 2 } \\
\text { LaCross } \\
\text { Lasalle 1 } \\
\text { Lasalle 2 } \\
\text { Monticello } \\
\text { Quad Cities } 1 \\
\text { Quad Cities 2 } \\
\text { Perry 1 } \\
\text { Perry 2 } \\
\text { Cooper } \\
\text { River Bend } \\
\text { WNP-2 }\end{array}$} & $\begin{array}{l}74 \\
75 \\
77 \\
77 \\
75 \\
35\end{array}$ & $\begin{array}{r}12 \\
12 \\
12 \\
12 \\
12 \\
7\end{array}$ & $\begin{array}{l}1 \\
4 \\
2 \\
2 \\
5 \\
6\end{array}$ & $\begin{array}{l}0.083 \\
0.333 \\
0.167 \\
0.167 \\
0.417 \\
0.857\end{array}$ \\
\hline & $\begin{array}{l}75 \\
79 \\
75 \\
63 \\
87\end{array}$ & $\begin{array}{r}12 \\
12 \\
12 \\
12 \\
5\end{array}$ & $\begin{array}{l}4 \\
3 \\
0 \\
0 \\
4\end{array}$ & $\begin{array}{l}0.333 \\
0.250 \\
0.000 \\
0.000 \\
0.800\end{array}$ \\
\hline & $\begin{array}{l}70 \\
71 \\
88\end{array}$ & $\begin{array}{r}12 \\
12 \\
4\end{array}$ & $\begin{array}{l}2 \\
5 \\
5\end{array}$ & $\begin{array}{l}0.167 \\
0.417 \\
1.250\end{array}$ \\
\hline & $\begin{array}{l}84 \\
84 \\
71 \\
73 \\
73 \\
87\end{array}$ & $\begin{array}{r}8 \\
8 \\
12 \\
12 \\
12 \\
5\end{array}$ & $\begin{array}{l}4 \\
0 \\
0 \\
5 \\
6 \\
6\end{array}$ & $\begin{array}{l}0.500 \\
0.000 \\
0.000 \\
0.417 \\
0.500 \\
1.200\end{array}$ \\
\hline & $\begin{array}{l}74 \\
86 \\
84\end{array}$ & $\begin{array}{r}12 \\
6 \\
8\end{array}$ & $\begin{array}{l}3 \\
2 \\
3\end{array}$ & $\begin{array}{l}0.250 \\
0.333 \\
0.375\end{array}$ \\
\hline All GE Plants & & 361 & 89 & 0.247 \\
\hline
\end{tabular}


Table 4.6 Room Cooler Data for a Typical PWR

\begin{tabular}{|l|c|c|c|c|}
\hline & \multicolumn{3}{|c|}{ Temperatures, F } & Dimensions, ft \\
\hline & Normal Abnormal & Accident & L $\times$ W $\times$ H \\
\hline RHR Pump Room & $120 / 65$ & 167 & 323 & $9 \times 9 \times 19$ \\
\hline RHR Heat Exchanger Room & $200 / 65$ & 226 & 323 & $16 \times 18 \times 15$ \\
\hline Auxil iary Feedwater Pump Room & $104 / 50$ & $104 / 36$ & 335 & $20 \times 30 \times 25$ \\
\hline Reactor Coolant Pump Cubicle & $120 / 65$ & 165 & 323 & $20 \times 30 \times 25$ \\
\hline Control Rod Drive Room & $200 / 65$ & 226 & 323 & $24 \times 50 \times 24$ \\
\hline Battery Room & $77 / 65$ & $77 / 65$ & 77 & $30 \times 22 \times 12$ \\
\hline Electrical Equipment Room & $104 / 50$ & $104 / 50$ & 104 & $74 \times 47 \times 1$ 'j \\
\hline ESF Electrical Switchgear Room & $86 / 50$ & $86 / 40$ & 104 & $49 \times 74 \times 25$ \\
\hline Cable Spreading Room & $104 / 50$ & $104 / 50$ & 104 & $60 \times 89 \times 12$ \\
\hline HVAC Room - Auxiliary Bldg. & $104 / 50$ & $104 / 50$ & 104 & $60 \times 57 \times 16$ \\
\hline Relay Room & $80 / 50$ & $80 / 50$ & 80 & $70 \times 70 \times 25$ \\
\hline Control Room & $78 / 72$ & $78 / 50$ & 78 & $60 \times 74 \times 15$ \\
\hline Computer Room & $77 / 73$ & $77 / 73$ & NA & $33 \times 37 \times 15$ \\
\hline $\begin{array}{l}\text { ECCS Cubicles (Low-head, High- } \\
\text { head Injection, Containment } \\
\text { Spray Pumps in Same Room) }\end{array}$ & $104 / 65$ & $104 / 49$ & 120 & $27 \times 34 \times 34$ \\
\hline Fuel Handling Bldg. HVAC Room & $104 / 65$ & $104 / 49$ & 120 & $46 \times 34 \times 38$ \\
\hline Centrifugal Charging Pump Room & $135 / 50$ & $135 / 44$ & 140 & $20 \times 20 \times 10$ \\
\hline Essential Chiller Room & $115 / 50$ & $115 / 44$ & 120 & $24 \times 109 \times 13$ \\
\hline Refueling Water Storage Tank Rm & $104 / 50$ & $111 / 44$ & 120 & $69 \times 58 \times 50$ \\
\hline Diesel Generator Cubicle & $104 / 50$ & $120 / 42$ & 120 & $35 \times 78 \times 29$ \\
\hline
\end{tabular}

NOTE: Normal conditions are assumed to exist on a continuous basis until an abnormal or accident condition occurs. Abnormal conditions are reasonably expected or anticipated deviations from normal conditions other than accident conditions. Accident conditions are unexpected events that could cause a release of radioactivity to the environs that could endanger public health and safety if not mitigated. 
Table 4.7 Room Cooler Data for a Typical BWR

\begin{tabular}{|l|c|c|c|c|}
\hline & \multicolumn{3}{|c|}{ Temperatures, F } & Dimensions, ft \\
\hline & Normal & Max & Min & L $\times$ W H \\
\hline Control Room & 75 & 100 & 60 & $60 \times 64 \times 16$ \\
\hline Battery Room & & 105 & & $42 \times 16 \times 16$ \\
\hline ESF Elec. Switchgear Room & & 105 & & $84 \times 40 \times 16$ \\
\hline Relay Room & & & & $43 \times 70 \times 16$ \\
\hline Cable Tray Area & & & & $38 \times 10 \times 16$ \\
\hline SGTS Room & 70 & 104 & 60 & $32 \times 28 \times 16$ \\
\hline Cable Spreading Room & & & & $46 \times 28 \times 14$ \\
\hline $\begin{array}{l}\text { Emergency Equipment Service } \\
\text { Nater Pump Room }\end{array}$ & & 104 & & $71 \times 25 \times 27$ \\
\hline EDG Room & & 122 & 65 & $33 \times 30 \times 27$ \\
\hline EDG Switchgear Room & & 104 & 65 & $37 \times 30 \times 20$ \\
\hline RHR Pump Room & 70 & 104 & 60 & $40 \times 40 \times 20$ \\
\hline RHR Heat Exchanger Room & & 148 & & $16 \times 17 \times 16$ \\
\hline Core Spray Room & 70 & 104 & 60 & $40 \times 40 \times 20$ \\
\hline RCIC Pump Room & 70 & 104 & 60 & $40 \times 40 \times 20$ \\
\hline HPCI Pump Room & 70 & 104 & 60 & $50 \times 51 \times 20$ \\
\hline RWCU Recirculation Pump Room & 70 & 104 & 60 & $14 \times 14 \times 14$ \\
\hline Recirc. Pump M-G Set Room & 128 & 135 & & $40 \times 50 \times 25$ \\
\hline Standby Liquid Control Room & & 100 & 70 & $26 \times 30 \times 25$ \\
\hline $\begin{array}{l}\text { Emergency Equipment Cooling } \\
\text { Water Heat Exchanger Room }\end{array}$ & & 148 & & $24 \times 20 \times 28$ \\
\hline NOTE: Nor & & & & \\
\hline
\end{tabular}

NOTE: Normal conditions are assumed to exist on a continuous basis until an abnormal or accident condition occurs. Abnormal conditions are reasonably expected or anticipated deviations from normal conditions other than accident conditions. Accident conditions are unexpected events that could cause a release of radioactivity to the environs that could endanger public health and safety if not mitigated. 
Iable 4.8 Reliability Data for Area/Room Coolers Based on LER Data

\begin{tabular}{|c|c|c|c|}
\hline Room/Area Cooler & $\begin{array}{l}\text { No of } \\
\text { Failures }\end{array}$ & \multicolumn{2}{|c|}{$\begin{array}{l}\text { Failure } \\
\text { To Start } \\
\text { Per Demand }\end{array}$} \\
\hline \multicolumn{4}{|l|}{ Normally Standby Components } \\
\hline $\begin{array}{l}\text { RHR Pump Room } \\
\text { Core Spray Pump Room } \\
\text { LPCI/LPCS Room } \\
\text { RCIC Pump Room } \\
\text { Emergency Gas Treatment System Room } \\
\text { Containment Coolers } \\
\text { ESF Switchgear Room } \\
\text { HPCI/HPCS Room } \\
\text { Emergency Diesel Generator HVAC } \\
\text { ESsential Service Water Pump Room } \\
\text { Containment Spray Pump Room }\end{array}$ & $\begin{array}{r}15 \\
12 \\
10 \\
9 \\
3 \\
1 \\
18 \\
24 \\
15 \\
7 \\
7\end{array}$ & \multicolumn{2}{|c|}{$\begin{array}{l}2.6 \mathrm{E}-03 \\
2.9 \mathrm{E}-03 \\
2.4 \mathrm{E}-03 \\
2.2 \mathrm{E}-03 \\
7.3 \mathrm{E}-04 \\
2.4 \mathrm{E}-04 \\
4.4 \mathrm{E}-03 \\
5.8 \mathrm{E}-03 \\
3.6 \mathrm{E}-03 \\
1.7 \mathrm{E}-03 \\
1.7 \mathrm{E}-03\end{array}$} \\
\hline \multirow[t]{3}{*}{ TOTAL } & 121 & & E-02 \\
\hline & \multirow{2}{*}{$\begin{array}{l}\text { No of } \\
\text { Failures }\end{array}$} & \multicolumn{2}{|c|}{ Failure Rate } \\
\hline & & Per RY & Per hr \\
\hline \multicolumn{4}{|l|}{ Normally Operating Components } \\
\hline $\begin{array}{l}\text { Control Rod Drive Power Supply Room } \\
\text { Reactor Building HVAC } \\
\text { Centrifugal Charging Pump Room } \\
\text { Control Room HAC - } 1 \text { Train } \\
\text { Control Room HVC - } 2 \text { Trains } \\
\text { Component Cooling Water Pump Room } \\
\text { Vital AC Inverter Room } \\
\text { Battery Room } \\
\text { Essential Chiller } \\
\text { Auxiliary Feedwater Pump Room } \\
\text { Electrical Penetration Rooms } \\
\text { Regenerative Heat Exchanger Room } \\
\text { Reactor Water Cleanup Pump Room }\end{array}$ & $\begin{array}{r}1 \\
2 \\
5 \\
25 \\
25 \\
16 \\
3 \\
4 \\
4 \\
9 \\
8 \\
3 \\
3 \\
8\end{array}$ & $\begin{array}{l}2.0 \mathrm{E}-03 \\
3.9 \mathrm{E}-03 \\
9.8 \mathrm{E}-03 \\
4.9 \mathrm{E}-02 \\
3.1 \mathrm{E}-02 \\
5.9 \mathrm{E}-03 \\
7.8 \mathrm{E}-03 \\
7.8 \mathrm{E}-03 \\
1.8 \mathrm{E}-02 \\
1.6 \mathrm{E}-02 \\
5.9 \mathrm{E}-03 \\
5.9 \mathrm{E}-03 \\
1.6 \mathrm{E}-02\end{array}$ & $\begin{array}{l}2.2 E-07 \\
4.5 E-07 \\
1.1 E-06 \\
5.6 E-06 \\
3.6 E-06 \\
6.7 E-07 \\
8.9 E-07 \\
8.9 E-07 \\
2.0 E-06 \\
1.8 E-06 \\
6.7 E-07 \\
6.7 E-07 \\
1.8 E-06\end{array}$ \\
\hline TOTAL & 91 & $1.8 \mathrm{E}-01$ & $1.0 E-05$ \\
\hline
\end{tabular}


large air-handling unit. Chilled water was not required to maintain room temperatures below the pump's design basis. However, a second plant located the component cooling water pumps and other safety-related pumps in separate small enclosed cubicles that require chilled water coolers to maintain temperatures below the pump design limits. In general, most of the LWR plants located the engineered safety feature (ESF) pumps in small enclosures with room coolers.

Our review of all the available information indicated that there were no significant commonalities or groupings between plant types or vendors, relative to HVAC or room cooler design, in the existing LWR plants. Each vendor or AE appeared to provide plant-specific room cooling system designs. Also, each plant seems to have "tailor-made" room cooling systems to accommodate the characteristics of the plant, probably on the basis of space limitations, the particular plant configurations, and geographic locations. The only noticeable commonality among all plant designs reviewed was that the control room HVAC system was separated and isolated from all other room cooling functions.

Because of this wide variability and the complexity of the investigation, it was impractical to examine in detail a large number of the existing LWR plants. It was then decided to select one plant from each vendor for detailed core damage frequency and public risk calculations. This was expected to ensure that the results are applicable to a large fraction of plants and to show whether there are significant differences in HVAC or room cooler-related CDF or public risk among vendors or plant types. Additionally, an assessment of HVAC or room cooler failure data was used to assist in selecting plants that had shown a number of room cooler failures. A summary of HVAC/room cooler malfunction events for the plants representing the four U.S. nuclear vendors is presented in Table 4.8 .

\subsection{ESF Dependencies on Room Coolers and Affected Accident Sequences}

The degree of ESF dependence on room cooling at selected nuclear power plants was determined through review of the FSAR, plant design data, and PRA documentation, and supplemented by information obtained during site visits. The purposes of the site visits were (1) to collect information needed to determine the temperature rise following a loss of room cooling in areas containing safety-related equipment and needed to determine the sensitivity of components to failure at elevated temperatures, (2) to discuss with plant personnel the design and operation of HVAC or room cooling systems, and (3) to identify and discuss potential accident sequences, recovery actions, and test and maintenance requirements. The list of ESF dependencies was used to identify the applicable fault trees containing HVAC or room cooling failures as basic events. Modifications were made to the fault trees where needed to incorporate HVAC/room cooler failures that were dismissed or otherwise not addressed in the existing PRAs. These modifications consisted of adding a series of events or additional branches to the fault trees to represent HVAC or room cooler failures.

To quantify the affected CDF and public risks, it is necessary to identify the accident sequences involving ESF failures that include contributions from failures of the HVAC or room cooling system. Room cooler failures, in general, are not modeled as initiating events in existing PRAs (Ref. 15). Rather, they are modeled as contributors to ESF system failures; 
i.e., room cooler failures may contribute to the unavailability of the lowpressure injection or the high-pressure injection functions. Contributions to CDF from room cooler failure, both as an initiator and as a contributor, are considered in this analysis.

Events involving room cooler failures identified in the event trees are presented in Table 4.9.

\subsection{Loss of Room Cooling as an Initiator}

Based on information in past PRAs and from reviews of historical data, a list of potential initiating events was developed. They are:

- Loss of electrical switchgear room cooling

- Loss of HPI pump room cooling

- Loss of LPI pump room cooling

- Loss of control building or control room cooling

The event trees for these initiating events were constructed from information collected from site visits, existing PRAs, and other plant-specific analyses using the same approach as described in NUREG-1150 (Ref. 6). The accident sequences obtained from the event trees were then quantified using the quantitative results from the fault trees developed in the PRA system analyses. The room cooler initiating event frequencies are shown on Table 4.10.

All sequences were retained in the quantification process and were analyzed further for potential operator recovery actions. The sequences were then quantified to include the effects of operator recovery actions. 
Table 4.9 Events Involving Room Cooler Failures Identified in Fault Trees

\begin{tabular}{|c|c|c|}
\hline System/Event & Event Description & Unavailability \\
\hline $\begin{array}{l}\text { Auxiliary } \\
\text { Feed Water }\end{array}$ & $\begin{array}{l}\text { AFW manual damper } 1124 \text { fails closed } \\
\text { AFW manual damper } 1682 \text { fails closed } \\
\text { AFW AC emergency fan fails to start } \\
\text { AFW AC emergency fan fails to run for } 5 \mathrm{hr} \\
\text { AFW manual damper } 1124 \text { fails closed } \\
\text { AFW manual damper } 1682 \text { fails closed } \\
\text { AFW DC emergency fan fails to start } \\
\text { AFW DC emergency fan fails to run for } 5 \mathrm{hr}\end{array}$ & $\begin{array}{l}1.0 E-3 \\
1.0 E-3 \\
3.0 E-3 \\
1.5 E-4 \\
1.0 E-3 \\
1.0 E-3 \\
3.0 E-3 \\
1.5 E-4\end{array}$ \\
\hline $\begin{array}{l}\text { Charging } \\
\text { Pump- } \\
\text { Recirculation }\end{array}$ & $\begin{array}{l}\text { Charging fan 1B-B fails to start } \\
\text { Charging fan } 1 B-B \text { fails to start(a) } \\
\text { Charging fan 1B-B fails to run for } 24 \mathrm{hr} \\
\text { Charging fan } 1 A-A \text { fails to run for } 24 \mathrm{hr}\end{array}$ & $\begin{array}{l}3.0 E-3 \\
3.0 E-3 \\
7.2 E-4 \\
7.2 E-4\end{array}$ \\
\hline $\begin{array}{l}\text { Containment } \\
\text { Spray } \\
\text { System }\end{array}$ & $\begin{array}{l}\text { Containment spray MDP1A fails to start } \\
\text { Containment spray MDP1A fails to run } 24 \mathrm{hr} \\
\text { CS MDP 1A-A unavailable due to T/M } \\
\text { Containment spray MDP1B fails to start } \\
\text { Containment spray MDP1B fails to run } 24 \mathrm{hr} \\
\text { CS MDP 1B-B unavailable due to } \mathrm{T} / \mathrm{M}\end{array}$ & $\begin{array}{l}3.0 E-3 \\
7.2 E-4 \\
2.0 E-3 \\
3.0 E-3 \\
7.2 E-4 \\
2.0 E-3\end{array}$ \\
\hline $\begin{array}{l}\text { Low Pressure } \\
\text { Injection } \\
\text { System- } \\
\text { Recirculation }\end{array}$ & $\begin{array}{l}\text { LPR Fan 1A-A fails to start } \\
\text { LPR Fan 1A-A fails to run for } 24 \mathrm{hr} \\
\text { LPR Fan 1A-A unavailable due to } \mathrm{T} / \mathrm{H} \\
\text { LPR Fan 1B-B fails to start } \\
\text { LPR Fan 1B-B fails to run for } 24 \mathrm{hr} \\
\text { LPR Fan 1B-B unavailable due to } \mathrm{T} / \mathrm{M}\end{array}$ & $\begin{array}{l}3.0 E-3 \\
7.2 E-4 \\
2.0 E-3 \\
3.0 E-3 \\
7.2 E-4 \\
2.0 E-3\end{array}$ \\
\hline $\begin{array}{l}\text { Safety } \\
\text { Injection } \\
\text { System- } \\
\text { Recirculation }\end{array}$ & $\begin{array}{l}\text { HPI Fan 1B fails to start } \\
\text { HPI Fan 1B fails to run for } 24 \mathrm{hr} \\
\text { HPI Fan 1A fails to start } \\
\text { HPI Fan 1A fails to run for } 24 \mathrm{hr}\end{array}$ & $\begin{array}{l}3.0 E-3 \\
7.2 E-4 \\
3.0 E-3 \\
7.2 E-4\end{array}$ \\
\hline
\end{tabular}


Table 4.9 Event Involving Room Cooler Failures

Identified in Fault Trees - (Cont'd)

\begin{tabular}{|c|c|c|}
\hline System/Event & Event Description & Unavailability \\
\hline $\begin{array}{l}\text { Electric } \\
\text { Power System } \\
\text { (EPS) }\end{array}$ & $\begin{array}{l}\text { EPS DG 1B-B fan fails to start } \\
\text { EPS DG 1B-B fan fails to run for } 6 \mathrm{hr}^{(b)} \\
\text { EPS DG manual damper fails closed }{ }^{(b)} \\
\text { Primary failure of DG 1B-B to start } \\
\text { EPS DG 1A-A fan fails to start } \\
\text { EPS DG 1A-A fan fails to run for } 6 \mathrm{hr}^{(b)} \\
\text { EPS DG manual damper fails closed }{ }^{(b)} \\
\text { Primary failure of DG 1A-A to start }\end{array}$ & $\begin{array}{l}3.0 E-3 \\
1.0 E-3 \\
3.0 E-3 \\
1.2 E-2 \\
3.0 E-3 \\
1.0 E-3 \\
3.0 E-3 \\
1.2 E-2\end{array}$ \\
\hline $\begin{array}{l}\text { DC Power } \\
\text { System }\end{array}$ & $\begin{array}{l}\text { Primary failure of Battery I } \\
\text { Battery I room fan fails to run } 6 \mathrm{hr}^{(\mathrm{b})} \\
\text { Battery I room damper transfer closed } \\
\text { Primary failure of Battery I(c) } \\
\text { Battery II room fan fails to run } 6 \mathrm{hr}^{(\mathrm{b})} \\
\text { Battery II room damper transfer closed }\end{array}$ & $\begin{array}{l}7.2 E-4 \\
7.2 E-4\end{array}$ \\
\hline $\begin{array}{l}\text { Steam } \\
\text { Generator } \\
\text { Tube Rupture } \\
\text { Sequence }\end{array}$ & $\begin{array}{l}\text { AFW DC emergency fan fails to start } \\
\text { AFW DC emergency fan fails to run } 5 \mathrm{hr} \\
\text { AFW manual damper A fails closed } \\
\text { AFW AC emergency fan fails to start } \\
\text { AFW AC emergency fan fails to run } 5 \mathrm{hr} \\
\text { AFW manual damper B fails closed }\end{array}$ & $\begin{array}{l}3.0 \mathrm{E}-3 \\
1.5 \mathrm{E}-4 \\
1.0 \mathrm{E}-3 \\
3.0 \mathrm{E}-3 \\
1.5 \mathrm{E}-4 \\
1.0 \mathrm{E}-3\end{array}$ \\
\hline
\end{tabular}

(a) Assumed to be operating at the time an incident occurs.

(b) Not included in fault tree analysis for representative W PWR. Fault trees were modified for this study to incorporate potential diesel generator room cooler failure.

(c) Included in fault tree analysis. Does not include contribution from failures of diesel generator room coolers. 
Table 4.10 Room Cooler Initiating Event Frequencies

\begin{tabular}{|l|c|c|c|}
\hline \multicolumn{1}{|c|}{ Room Cooler } & $\begin{array}{c}\text { Number } \\
\text { of Failures, } \\
\text { All modes }\end{array}$ & $\begin{array}{c}\text { Number } \\
\text { of Failures, } \\
\text { Operating }\end{array}$ & $\begin{array}{c}\text { Initiator } \\
\text { Frequency, } \\
\text { per RY }\end{array}$ \\
\hline LPI/LPR Pump room cooler (a) & 25 & 12 & $2.34 E-02$ \\
\hline HPI/HPR Pump room cocler ${ }^{(b)}$ & 45 & 19 & $3.71 E-02$ \\
\hline Control Room HVAC system & 41 & 23 & $4.49 E-02$ \\
\hline ESF Switchgear room cooler & 18 & 10 & $1.95 E-02$ \\
\hline
\end{tabular}

(a) Includes failures of RHR systems, LPI/LPR at PWRs, and BWR lowpressure core spray and low-pressure coolant injection systems (LPCS/LPCI).

(b) Included failures of PWR HPI/HPR systems and BWR reactor core isolation cooling systems, high pressure core spray, and high pressure coolant injection systems (HPCS/HPCI).

Failures that occurred during plant shutdown are less critical (Ref. 13) because the lower decay heat levels allow a much longer time for the operator to diagnose and correct room cooler failures than while the plant is operating. For this reason, it is unlikely that loss of a room cooler during shutdown conditions could lead to a core damage event.

Recovery from a loss of room coolers may be a relatively simple procedure and in most cases can be accomplished using equipment on hand. For example, fan belts often break and require replacement. Most utilities carry replacement fan belts in their spare part programs. Most plants also have portable fans that may be used to introduce cool air from one room to another, thus providing cooling to a room in which the coolers have failed. The portable fans may be supplemented by flexible, portable ducts to facilitate the flow of air from one room to another. Other possibilities may be to simply open room doors or open cabinets to facilitate the flow of air (Refs. $4,15)$.

The probability of recovery from room cooler failure initiating events was evaluated on the basis of room heatup times and backup room cooling capabilities. The non recovery probability was estimated using the methodology described in NUREG/CR-4834 (Ref. 16).

Thus:

$$
P(N R)=P(N D)+P(N A)-P(N D) * P(N A)
$$

where $\quad P(N R)=$ Probability of failure to recover

$P(N D)$ - Probability of failure to diagnose appropriate action

$P(N A)$ - Probability of failure to reach appropriate area

of plant and accomplish action 


\subsubsection{CDF Quantification for Internal Events}

The core damage accident sequences were developed and quantified according to the new event trees established previously. PNL used the original cut sets from the existing PRAs for transients with main feedwater initially available. Each of the cut sets was examined to determine which basic event would be affected by a loss of room cooler function. The affected parameters and their values were modified to account for the possibility of prior failure of room coolers. The assumptions used to modify the affected values and the detailed calculations are presented in Reference 1. Table 4.11.

The mean cut set frequency for each of the initiators is presented in

Table 4.11 Assessed Mean CDF with Room Cooler Failure as Initiator Event

\begin{tabular}{lc}
\multicolumn{1}{c}{ Initiator } & $\begin{array}{c}\text { Frequency } \\
\text { Per RY }\end{array}$ \\
Switchgear Room & $1.1 E-06$ \\
Control Room & $7.3 E-07$ \\
HPI Room & $4.1 \mathrm{E}-08$ \\
LPI Room & $2.9 \mathrm{E}-09$ \\
DC Equipment Room & $1.6 \mathrm{E}-07$
\end{tabular}

The mean total CDF from room cooler failure initiators was estimated to be $2.0 E-6 / R Y$.

Approximately $58 \%$ of the CDF from room cooler initiators results from failure of ESF switchgear room coolers. Failure of control room cooler contributes $39 \%$ of the CDF. Approximately $2 \%$ of the CDF arises from HPI/HPR pump room cooler initiators, and less than $1 \%$ arises from failure of LPI/LPR pump room coolers.

\subsubsection{Public Risk Quantification for Internal Events}

The minimal cut sets developed in the previous section were grouped into plant damage states (PDSs). Each PDS provides similar initial conditions for the subsequent accident progression analysis. The accident progression analysis used large event trees to determine the possible path through which an accident might evolve (Ref. 14). The paths through the accident progression avent trees are then grouped into accident progression bins (APBs) which provide similar initial conditions for the subsequent source term analysis. The results of the accident progression analysis are probabilities for each APB, given the occurrence of a PDS. A source term is then computed for each APB that defines the quantities of radioactive material released to the environment. Consequence calculations are then performed for each APB source term. The APB assignments to source term groups and the conditional probabilities of the various source term groups were developed in Reference 14. The public risk may be expressed as: 


$$
R I S K=\Sigma_{i, j} \quad\left(C D F * A P B_{1} * S T G * C_{i, j}\right)
$$

where: $A P B_{1}=$ Conditional probability of accident progression bin "i"

$$
\begin{aligned}
& S T G_{i, j}=\quad \begin{array}{l}
\text { Conditional probability for each source } \\
\text { term group "j" for each accident } \\
\text { progression bin " } i "
\end{array} \\
& C_{i, j}=\begin{array}{l}
\text { Consequence for source term group " } j " \\
\text { associated with each accident progression } \\
\text { bin " } j "
\end{array}
\end{aligned}
$$

The mean public risk associated with room cooler initiators for a typical representative PWR was estimated to be $4.0 \mathrm{E}-01$ person-rem/RY. The affected CDF and public risks due to initiating events for other representative LWRs are shown in Table 4.12.

Table 4.12 Affected CDF and Public Risk for the Representative Plants from Room Cooler Initiator

\begin{tabular}{|l|c|c|c|c|}
\hline \multirow{2}{*}{$\begin{array}{l}\text { Affected CDF } \\
\text { per reactor-year }\end{array}$} & W PWR & BWR & CE PWR* & B\&W PWR \\
\cline { 2 - 5 } & $2.04 E-06$ & $4.7 E-07$ & $1.3 E-06$ & $5.7 E-08$ \\
\hline $\begin{array}{l}\text { Effect on Public } \\
\text { Risks } \\
\text { Person-rem } \\
\text { per reactor-year }\end{array}$ & $4.0 E-01$ & $2.3 E-01$ & $7.2 E-01$ & $1.5 E-01$ \\
\hline
\end{tabular}

* HVAC/room cooler initiators and contributing elements were combined into a single analysis.

\subsection{Loss of Room Cooling as Contributor}

PNL reviewed and compared the SARA and IRRAS data files with the fault trees developed in the previous sections. The basic events containing room cooler failures were identified and retained for the cumulative cut set frequency calculation. The cut sets for events that could be affected by room cooler failure but were not considered in the original PRA, such as loss of offsite power, were modified to incorporate room cooler failure sequences. The SARA or IRRAS computer code was used to assign each cut set an accident. sequence and PDS. The affected CDF was determined by totaling the frequencies of all the cut sets containing one of the basic events.

The public risk was estimated in much the same manner expressed in the previous section. Each accident sequence was examined in the existing PRA to determine the progression of each sequence following core damage through 
containment failure and release of radioactive materials to the environment (Ref. 1). The results of the analysis are presented in Table 4.13.

Table 4.13 Summary of Affected CDF and Public Risk Results for the Representative Plants from Internal Events

\begin{tabular}{|c|c|c|c|c|}
\hline & \multicolumn{3}{|c|}{ P1 ant Type } \\
\cline { 2 - 5 } & W PWR & BWR & CE PWR* & B\&W PWR \\
\hline $\begin{array}{c}\text { Affected CDF, } \\
\text { per reactor-year } \\
\text { Initiator } \\
\text { Contributor }\end{array}$ & $2.04 E-06$ & $4.71 E-07$ & $1.3 E-06$ & $5.7 E-08$ \\
\hline \multicolumn{1}{|c|}{ TOTAL } & $2.6 E-05$ & $2.6 E-07$ & & $1.6 E-07$ \\
\hline $\begin{array}{l}\text { Public Risks person-rem per reactor-year } \\
\text { Initiator } \\
\text { Contributor }\end{array}$ & $4.6 E-06$ & $7.3 E-07$ & $1.3 E-06 *$ & $2.2 E-07$ \\
\hline \multicolumn{1}{|c|}{ TOTAL } & $4.0 E+01$ & $2.3 E-01$ & $7.2 E-01$ & $1.5 E-01$ \\
& $1.7 E+00$ & $1.2 E-01$ & & $3.8 E-02$ \\
\hline
\end{tabular}

* HVAC/room cooler initiators and contributing elements were combined into a single analysis.

\subsection{Assessment of Affected CDF from External Events}

Event trees and fault trees developed for the internal events analyses were used with modifications to incorporate equipment failures caused by external events such as seismic events, fires, floods and tornados.

During a seismic event, there are three possibilities that the safetyrelated system could fail. These are:

- The seismic event directly fails the safety-related system but not the room cooler

- The seismic event directly fails the safety-related system and the room cooler

- The seismic event fails the room cooler but leaves the safety-related system intact. 
All these possibilities have been addressed in the system failure probability model described in an existing PRA (Ref. 17). The third scenario is the only one of interest to this study. The methodology and logic used in this analysis follow the same approach as described in Reference 17, i.e., the unavailability of a safety-related system is approximately the sum of the failure probability of individual component in that system. That is:

where

$$
\text { P (safety system) } \quad \boldsymbol{\Sigma}_{1} \quad \mathbf{P}_{1}
$$

$$
\begin{aligned}
& \mathbf{p}=\text { failure probability } \\
& \mathbf{i}=\text { individual safety system components }
\end{aligned}
$$

Component-level fragility data (Ref. 17) were used to separate the HVACrelated seismic CDF from the total seismic CDF. The median fragility values for individual components represent the median seismic acceleration required to fail the components. The failure probability of a given component is a function of its median fragility value as follows:

$$
P=f\left(m_{f, 1}\right)
$$

where

$$
\begin{aligned}
& \mathbf{P}_{1}=\text { Failure probability of component } i \\
& m_{f, 1}=\text { Median fragility of component } i
\end{aligned}
$$

\subsubsection{Seismic}

To quantify the seismic-induced safety system failure probabilities from individual HVAC and room cooler equipment failures, a component failure factor is developed for the calculation. The value for the factor $(Z)$ is related to the probabilities of component failures given a seismic event, and thus is a function of the median fragilities of HVAC or room cooler components relative to the median fragilities of the more seismic-sensitive components of the ESF system. The value of $\mathbf{Z}$ was approximated using the ratio of the failure probabilities of HVAC or room cooler components to the failure probability of the safety system. Therefore,

$$
\text { where } \quad \begin{aligned}
& Z_{n}=\mathbf{P}_{\mathrm{HVAC}} / \mathbf{P}_{\mathrm{S}, \mathrm{N}} \\
& \mathbf{Z}_{\mathrm{N}}=\text { Failure factor } \\
& \mathbf{P}_{\mathrm{HVAC}}=\text { Failure probability of HVAC component } \\
& \mathbf{P}_{S, N}=\text { Failure probability of safety system }
\end{aligned}
$$

The factor $Z$ represents the fraction of safety system failures that are attributable to seismic-induced failures of HVAC or room cooling components only.

The frequencies of seismic accident sequences are the products of seismic initiating-event frequencies and conditional safety system failure probabilities, i.e.,

$$
=\boldsymbol{T}_{\mathrm{SI}}{\underset{\mathrm{K}=1}{\boldsymbol{N}} \mathbf{R}_{\mathrm{S}, \mathrm{K}}}^{\mathbf{N}}
$$


where

$$
P_{S, N}=\sum_{K=1}^{r} P_{1, K}
$$

$$
\begin{aligned}
& P_{f, k} \approx F \quad\left[\ln \left(\boldsymbol{H}_{f, k}\right) / \boldsymbol{M}_{f, k}\right] \\
& n \\
& P_{s, n}=\sum_{k=1}\left\{F\left[\left(\ln \left(m_{r, k} / m_{r, k}\right)\right]\right\}\right.
\end{aligned}
$$

and

where

$$
F[x]=\int_{-\infty}^{x}\left\{\left[1 /(2 \pi \sigma] \exp \left\{-0.5[(x-\mu) / \sigma]^{2}\right\}\right\} d x\right.
$$

$$
\begin{aligned}
& \boldsymbol{T s i}=\text { Seismic initiating event frequency } \\
& \mathbf{P}_{f, k}=\text { Failure probability of individual component } \\
& \mathbf{F}=\text { Standard normal cumulative distribution function } \\
& \mathbf{m}_{r}=\text { Median response } \\
& m_{f}=\text { Median fragility }
\end{aligned}
$$

The affected portion of a seismic accident sequence that contains HVAC/room cooler failures was estimated according to the ratio of seismic failure probabilities of HVAC components to failure probability of the safety system supported by HVAC. That is :

$$
R_{n} \text {, affected }=\left[P_{s, n}-P_{s, o}\right] / P_{s, n}
$$

where

$$
\begin{array}{lll}
P_{s, 0} & = & P_{s, m}-P_{\text {HVAC,n }} \\
m & =P_{\text {HVAC ,N }} / P_{s, n}
\end{array}
$$

The affected CDF is then calculated according to:

$$
\text { saffected }=\text { soriginal }_{\text {a }}=\underset{k=1}{Z_{n}} R_{k} \text {, affected }
$$

A total of ten accident sequences for a typical PWR were considered, the total affected CDF was calculated to be 8.4 E-08/RY. For a typical BWR, a total of 22 sequences were involved, and the total affected CDF was about 1.9 E-08/RY.

\subsubsection{Fire}

As with the seismic analysis, a screening process was performed to identify the risk-significant locations in the plant in which fire could occur. This was accomplished by identifying fire zones in which safetyrelated equipment or control cables are located, quantifying fire-induced initiating event frequencies in these zones, and then screening each zone on the initiating event frequency as well as on both order and frequency of cut sets leading to core damage. The sequences remaining afterward included fires in the control room, emergency switchgear room, cable spreading room, cable 
vault, auxiliary building, emergency switchgear room, and charging pump service water pump room at the PWR. The most fire-sensitive areas in the plant are the emergency switchgear room, the main control room and the DC equipment room. Because both BWRs and PWRs have these areas, separate CDF calculations for both plant types were not developed. The CDF calculations presented herein are considered applicable to both types of plants.

Detailed core damage frequency analyses were performed for the probabilistically significant sequences related to these fire sensitive areas.

The steps in the quantification methodology are:

1. Determine the temperature response in each fire zone. The COMPBRN fire growth code was used to calculate fire propagation and equipment damage.

2. Estimate fire barrier failure probabilities. These data were used to evaluate adjacent fire zones.

3. Perform recovery analysis.

4. Perform uncertainty calculations.

The affected CDF for a fire sequence involving failure of a safetyrelated equipment room is estimated according to the general expression:

$$
=T * f a * Q(T g) *\left(Q s+Q_{\text {HVAC }}\right) * R o p
$$

where

$$
\begin{aligned}
& =\mathrm{CDF} \\
& T \text { = Frequency of safety-related equipment room } \\
& \text { fire } \\
& \text { fa = Area fraction (HVAC equipment room/safety- } \\
& \text { related area) } \\
& Q(T g)=\text { Percentage of fire not suppressed before } \\
& \text { critical damage to component in fire zone } \\
& \text { occurs. } \\
& \text { QS = Random unavailability of supporting system } \\
& \mathbf{Q}_{\text {Havc }}=\text { Random unavailability of HVAC system } \\
& \text { Rop = Probability that operator fails to provide } \\
& \text { supplementary cooling }
\end{aligned}
$$

As an example, consider the effects and consequences caused by a fire in the control room emergency HVAC (CRAC) system equipment room. The CRAC equipment is safety-related and subject to Technical Specifications and Limiting Conditions for Operation. The equipment is normally located in the control or the auxiliary building, often in rooms adjacent to the main control room. It was assumed that a fire in the CRAC equipment room would result in failure of all trains of emergency control room cooling. A reactor shutdown is required when a total loss of CRAC occurs. 
Failure of the CRAC system results in a loss of control room cooling, which causes room temperature to rise in the control room. Spurious alarms and equipment actuation and incorrect readings on instrumentation and control equipment could result if the control room temperature exceeds the equipment qualification temperatures. Operators may elect to abandon the control room and try to control the plant from the remote shutdown panel. At all the plants visited in this study, tise remote shutdown room was cooled by a separate safety-related HVAC system. Therefore, it is possible for the operator to shut down the plant from the remote shutdown panel should the control room become uninhabitable or if the main control room equipment fails because of a fire in the CRAC equipment room.

The core damage frequency resulting from CRAC equipment room fire may be expressed as:

where

$$
=T c r * f r * R c r * R o p
$$

$=\mathrm{CDF}$

$\tau C r=$ Frequency of CRAC equipment room fire

Rop = Probability that operators fail to restore the CRAC system

$\mathrm{fr}=$ Probability that heat will force control room abandonment

Rcr = Probability that operators fail to that plant from the remote shutdown panel

Similar expressions can be used to calculate the fire-affected CDF for the switchgear room and the DC equipment room. The total fire-affected CDF is presented in Table 4.14 . 
Table 4.24 Affected CDF From Fires

\begin{tabular}{|l|c|c|c|c|}
\hline & \multicolumn{2}{|c|}{$\begin{array}{c}\text { Original } \\
\text { CDF, per RY(o) }\end{array}$} & \multicolumn{2}{c|}{$\begin{array}{c}\text { Affected } \\
\text { CDF, per RY }\end{array}$} \\
\hline Fire Location & PWR & BWR & PWR & BWR \\
\hline Control Room & $1.58 E-06$ & $6.20 E-06$ & $1.92 E-06$ & $1.92 E-06$ \\
\hline $\begin{array}{l}\text { Emergency Switch- } \\
\text { gear Room }\end{array}$ & $6.09 E-06$ & $1.30 E-05$ & $3.70 E-06$ & $3.70 E-06$ \\
\hline $\begin{array}{l}\text { DC Equi pment } \\
\text { Room }\end{array}$ & $\begin{array}{c}\text { Not } \\
\text { Evaluated }\end{array}$ & $\begin{array}{c}\text { Not } \\
\text { Evaluated }\end{array}$ & $1.49 E-06$ & $1.49 E-06$ \\
\hline Total $^{(b)}$ & $1.13 E-05$ & $2.00 E-05$ & $7.11 E-06$ & $7.11 E-06$ \\
\hline
\end{tabular}

(a) Source: Reference 17 for PWRs and BWRs, respectively, for values given in the table.

(b) The original CDFs include contributions from fires in the cable vault/tunnel and charging pump service water pump room that are not affected by this Generic Issue, as well as the locations listed in the table. The original CDF for the BWR includes contributions from fires in the cable spreading room that are not affected by this Generic Issue, as well as the locations listed in the table.

\subsubsection{Flood}

The methodology and data used in this study to estimate the affected CDF from floods (for both PWR and BWR) involving HVAC and room cooler systems were derived primary from two existing IPEs (Refs. 17, 26). Event trees were developed and evaluated to model the progression of events and safety system failures in potential flood-accident sequences. It has been shown in the previous sections that the critical areas of this analysis are the HVAC equipment rooms serving the switchgear, DC equipment, and control room. Internally induced floods are more likely sources of core damage than external floods. The CDFs caused by external floods were el iminated from IPEs (for both PWRs and BWRs) on the basis that most of the safety-related areas are typically located well above elevations of external flood levels, the frequencies of externally initiated floods are low, and the conditional probabilities that the floods affect the HVAC and room cooling system cause a negligible contribution to the total CDF. The room coolers in ESF pump rooms were eliminated from this analysis on the basis that they are located above the floors and, in most cases, well above the elevations of the ESF pumps. Should a flood occur in these rooms, the flood would reach a level that fails the pump before it could cause the room cooler to fail.

The expression used to estimate the CDF for both PWRs and BWRs, associated with internal flooding of HVAC equipment, is similar to that for fire analysis and is shown below: 


$$
\begin{aligned}
& \text { where }=\tau_{f} * R_{c r} * R_{o p} \\
& -\quad=\operatorname{CDF} \\
& \text { If - Frequency of HVAC equipment room floods } \\
& \text { Rop = Probability that operators fail to restore the } \\
& \text { HVAC system } \\
& \text { RCr = Probability that operators fail to recover } \\
& \text { the plant from the remote shutdown panel }
\end{aligned}
$$

The results of internal flooding assessment are summarized in Tables 4.15A and 4.15B

\subsubsection{Tornadoes}

The effects of tornadoes on nuclear plant structures, systems, and componen. are considered in plant designs and siting decisions in accordance with $10 \mathrm{C}^{-}$? Part 50 and $10 \mathrm{CFR}$ Part 100 , respectively. Tornadoes produce high winds that nay directly impact external structures. The frequency of tornadoes of sufficient intensity to produce significant structural damage at a nuclear pl it site depends on the region in which the plant is located. In general, tori. to strike probabilities and intensities are much greater in the Eastern Regioi than the Western Region of United States (Ref. 27).

The frequency of tornadoes severe enough to result in failure of buildings housing HVAC or cooler equipment was estimated to be about 3.6E05/YR for Eastern plants and less than 1.2E-07/YR for the Western plants (Ref. 27). These initiating events must be followed by safety system failures to lead to a core damage accident. A single tornado is not likely to fail redundant trains of the emergency core cooling system, for example, because of the abilities of buildings containing safety-related components to withstand high wind loadings. Buildings also can provide protection to other buildings against tornado winds because they provide intervening shielding.

Furthermore, the conditional probability that a tornado fails HVAC/room cooler components but does not fail the components served by the HVAC system is small relative to the probability that the tornado directly causes the safetyrelated components to fail. Additionally, the probability that HVAC/room cooler components fail as a result of the tornado high winds was shown to be less likely than failure of the components served by the HVAC/room cooler systems due to the time available to restore some form of room cooling (Ref. 31). It was then concluded that the CDF attributable to tornado-induced failures of HVAC/room coolers is insignificant relative to other external and internal events.

The total CDF from external events that involves a loss of room cooling function is the sum of CDF from seismic events, fires, and floods. The results are summarized in Tables 4.16 and 4.17 .

For both PWRs and BWRs, the affected CDF is dominated by a few accident sequences. The dominant accident sequences primarily involve station blackout situations, although the exact causes of station blackout are somewhat different among plant types. For example, at the representative BWR, the most important cause of failure of the emergency ac power system was failure to 
Another observation is that the affected fire-induced CDF is a much larger fraction of the total CDF than the corresponding fraction of the seismic-induced CDF. The main reason is that the HVAC and room cooling equipment is much less vulnerable to seismic-induced failures than other safety system components such as pumps and valves. Obviously, failure of the HPI pump is a more critical fallure than a room cooler failure because of the possibility of restoring some form of HPI pump room cooling. On the other hand, if an external event fails the HPI pump, it becomes immediately unavailable and is not likely to be recovered in time to prevent core damage. Therefore, under external event conditions, failures of the ESF system components are more critical, and tend to dominate the CDF, than failures of HVAC and room cooling equipment.

Table 4.15A Summary of Flood-Induced Affected CDF for $W$ and CE PWRS and GE BWRs

\begin{tabular}{|l|c|}
\hline Flood Location & $\begin{array}{c}\text { Affected } \\
\text { CDF, per RY }\end{array}$ \\
\hline $\begin{array}{l}\text { Emergency Switchgear } \\
\text { Room HVAC }\end{array}$ & $5.15 \mathrm{E}-07$ \\
\hline Control Room HVAC & $4.23 \mathrm{E}-07$ \\
\hline $\begin{array}{l}\text { DC Equipment Room } \\
\text { HVAC }\end{array}$ & $5.71 \mathrm{E}-08$ \\
\hline TOTAL & $9.95 \mathrm{E}-07$ \\
\hline
\end{tabular}


Table 4.15B Summary of Flood-Induced Affected CDF for a B\&W PWR

\begin{tabular}{|l|c|}
\hline $\begin{array}{l}\text { Flood } \\
\text { Sequence }\end{array}$ & $\begin{array}{c}\text { Affected Core Damage } \\
\text { Frequency, Per RY }\end{array}$ \\
\hline $\begin{array}{l}\text { Equipment Room } \\
\text { HPI Room and } \\
\text { Related Areas }\end{array}$ & $1.00 E-12$ \\
\hline TOTAL & $2.39 E-06$ \\
\hline
\end{tabular}




\section{Table 4.16 Summary of Affected CDF due to External Events}

\begin{tabular}{|c|c|c|c|c|c|c|c|}
\hline \multirow[b]{2}{*}{ External Event } & \multicolumn{2}{|c|}{$\begin{array}{l}\text { Original } \\
\text { CDF, per RY }\end{array}$} & \multicolumn{2}{|c|}{$\begin{array}{c}\text { Affected } \\
\text { CDF, per RY }\end{array}$} & \multicolumn{2}{|c|}{$\begin{array}{c}\text { Fraction, } \\
\text { Affected: Total }\end{array}$} & \multirow{2}{*}{$\begin{array}{l}\text { Report } \\
\text { Section }\end{array}$} \\
\hline & PWR & BWR & PWR & BWR & PWR & BWR & \\
\hline Seismic & $1.12 E-04$ & $7.66 \mathrm{E}-05$ & $8.42 E-08$ & $1.92 E-06$ & 0.0008 & 0.0003 & 5.1 \\
\hline $\begin{array}{l}\text { Fire } \\
\text { - Control room } \\
\text { - DC equipment } \\
\text { room } \\
\text { - Emergency } \\
\text { switchgear } \\
\text { room }\end{array}$ & $\begin{array}{c}1.58 E-06 \\
\text { Not } \\
\text { Evaluated } \\
6.09 E-06\end{array}$ & $\begin{array}{c}6.20 \mathrm{E}-06 \\
\text { Not } \\
\text { Evaluated } \\
1.30 \mathrm{E}-05\end{array}$ & $\begin{array}{l}1.92 E-06 \\
1.49 E-06 \\
3.70 E-06\end{array}$ & $\begin{array}{l}1.92 E-06 \\
1.49 E-06 \\
3.70 E-06\end{array}$ & (a) & (a) & $\begin{array}{l}5.2 .3 \\
5.2 .2 \\
5.2 .1\end{array}$ \\
\hline Total fire & $1.13 E-05$ & $1.95 E-05$ & $7.11 E-06$ & $6.11 E-06$ & 0.63 & 0.63 & \\
\hline $\begin{array}{l}\text { Flood } \\
\text { - Control room } \\
\text { - DC equipment } \\
\text { room } \\
\text { - Emergency } \\
\text { switchgear } \\
\text { room }\end{array}$ & $\begin{array}{c}\text { Not } \\
\text { Evaluated }\end{array}$ & $\begin{array}{c}\text { Not } \\
\text { Evaluated }\end{array}$ & $\begin{array}{l}4.23 E-07 \\
5.71 E-08 \\
5.15 E-07\end{array}$ & $\begin{array}{l}4.23 E-07 \\
5.71 E-08 \\
5.15 E-07\end{array}$ & $\begin{array}{l}- \\
-\end{array}$ & $\begin{array}{l}- \\
- \\
-\end{array}$ & $\begin{array}{l}5.3 .1 .3 \\
5.3 .1 .2 \\
5.3 .1 .1\end{array}$ \\
\hline $\begin{array}{l}\text { Total Flood } \\
\text { "Generic" } \\
\text { BWR, PWR }\end{array}$ & $2.80 \mathrm{E}-05$ & $2.80 E-05$ & $\begin{array}{l}9.95 E-07 \\
2.39 E-06\end{array}$ & $9.95 \mathrm{E}-07$ & $\begin{array}{l}0.036 \\
0.085\end{array}$ & 0.036 & 5.3 .2 \\
\hline Tornadoes & $9.70 E-06$ & $9.70 E-06$ & Neg. & Neg. & - & - & 5.3 .3 \\
\hline $\begin{array}{l}\text { Total External } \\
\text { Event CDF }\end{array}$ & $1.61 E-04$ & $1.34 E-04$ & $8.19 E-06$ & $8.12 E-06$ & 0.05 & 0.06 & \\
\hline
\end{tabular}

NOTE: Neg. = Negilible. CDF less than 1E-08/RY. Excess significant figures are retained for calculation purposes.

(a) The affected portions of the individual fire sequence frequencies are not calculated because a combined PWR and BWR fire-induced CDF was calculated. This appears to be reasonable given that the difference between the total fire-induced CDF for PWRs and BWRs are approximately equal. 
Table 4.17 Summary of Affected Public Risk Values due to External Events

\begin{tabular}{|l|c|c|c|c|}
\hline \multirow{2}{*}{$\begin{array}{l}\text { External } \\
\text { Event }\end{array}$} & \multicolumn{4}{|c|}{ Affected Public Risk, person-rem/RY } \\
\cline { 2 - 5 } & W PWR & CE PWR & GE BWR & B\&W PWR \\
\hline Seismic & $5.7 E-02$ & $5.7 E-02$ & $9.5 E-03$ & $5.7 R-02$ \\
\hline Fire & $4.8 E+00$ & $4.8 E+00$ & $3.4 E+00$ & $4.8 E+00$ \\
\hline Flood & $6.8 E-01$ & $6.8 E-01$ & $4.8 E+i 1$ & $1.5 E+00$ \\
\hline Tornado & Neg & Neg & Neg & Neg \\
\hline TOTAL & $5.6 E+00$ & $5.6 E+00$ & $3.9 E+00$ & $6.3 E+00$ \\
\hline
\end{tabular}




\section{VALUE/IMPACT ANALYSIS}

The value/impact (V/I) methodology for analyzing the various alternatives examined under this study is based on the requirements of the backfit rule (10 CFR 50.109) and related guidance contained in References 18, 19 , and 28. One of the primary considerations here is the derivation of a cost/benefit ratio for each alternative evaluated in terms of cost in dollars per person-rem averted, which may be compared to a guideline such as $\$ 1000$ per person-rem. This quantitative guideline is one of the elements considered in the decision-making process. In addition, the backfit rule requires that the proposed action provide a substantial increase in the overall protection of public health and safety. Deterministic considerations on the merits of a proposed alternative resolution are also a part of the decision with respect to a given alternative (see Section 6 ). The following sections present a description of each alternative and the results of a value/impact assessment. Table 5.1 summarizes the results of this assessment for the following alternatives that were analyzed.

5.1 Alternative 1 - No Action - Under this alternative there will be no new regulatory requirements. Consistent with existing regulations, this alternative does not preclude a licensee, or an applicant for an operating license, from proposing to the NRC staff any design changes intended to enhance the reliability or operability of the HVAC or room cooling system and its components on a plant-specific basis.

5.2 Alternative 2 - This alternative is the minimum-cost, minimum-benefit alternative. It consists of the following resolution elements: (1) perform room heatup calculations and thermal fragility analysis, (2) review the HVAC/room cooler system design, (3) enhance the preventive maintenance and testing program, and (4) improve emergency procedures.

The benefits derived from preforming room heat up calculations and thermal fragility analyses include identifying temperature-sensitive equipment in areas that may heat up rapidly. This will indicate to plant operators which locations may be most vulnerable to a loss of HVAC or room cooling. This information would be used to guide implementation of subsequent measures designed to prevent or mitigate failures of safety-related equipment from high room temperature. In addition, this study will provide an indication of the amount of time available for the operator to recover from a loss of room cooling. This information would provide a useful guide to the type of preventive/mitigative strategies that would be most successful. A further benefit of this study would be that the results can provide a useful guide for identifying rooms or specific locations that would benefit from installing of remote temperature-monitoring/alarm capabilities. The remote temperaturemonitoring/alarm equipment would effectively alert operators of potential HVAC failures and the threat of associated equipment malfunctions.

The purpose of HVAC system design review, resolution element 2 , is to identify any design deficiencies identified in this study. For example, a PWR plant (Ref. 20) recently conducted a preliminary assessment of the fuelhandling building ventilation system and the auxiliary building ventilation system designs and determined that loss of dc power to the control of one auxiliary building ventilation system ventilation train could also cause a 
loss of the fans in the other train. The auxiliary building ventilation system appeared susceptible to a common mode failure. Other plants, PWRs or BWRs, may have similar common mode failure problems not yet uncovered. A system design review could help to identify such deficiencies that could be rectified with appropriate corrective action.

Although the HVAC personnel at the plants visited in this study did not specifically mention that the system is given a low priority, it was apparent from the LER review that numerous maintenance errors and preventivemaintenance-related failures have occurred at the plant. The enhanced preventive maintenance and testing program (resolution element 3) could be tailored to meet plant-specific needs. Plants were observed to keep comprehensive records of failures and maintenance of HVAC equipment. HVAC and systems engineers at the plant are also aware of specific maintenance-related problems. Therefore, a plant-specific preventive maintenance and testing program that focuses on the most vulnerable HVAC equipment could be established. As a minimum, the enhanced preventive maintenance program could evaluate the reliability of the essential chiller, ventilation or fire dampers, and air handling units, including the fans and associated heat exchanger.

The purpose of resolution element 4, improving emergency procedures, is to ensure that emergency procedures addressing loss of HVAC or room cooling functions are available and operators are trained in their implementation. Based on discussions with plant operators, emergency procedures do exist, at least at the plants visited in this study, to cope with the loss of HVAC or room cooling. However, there were indications in the literature reviewed in this study that some plants do not have such emergency procedures. These plants should examine their existing emergency procedures and develop adequate procedures to cope with the loss of HVAC/room cooling systems and increases in room temperature.

5.3 Alternative 3 - Alternative 3 includes all the elements of Alternative 2 plus (1) installation of remote room temperature monitors or alarms and (2) installation of portable air conditioning equipment.

The first element of this alternative involves installation of remote temperature-monitoring systems in the plant's most vulnerable areas, i.e., areas that heat up rapidiy following a loss of room cooling and that contain temperature-sensitive equipment. The remote temperature-monitoring systems could be designed to continuously measure room temperatures, read out in the control room, and could be designed to alarm when temperatures rise to the point at which safe operating limits begin to be threatened.

The second element involves installation of portable cooling equipment to improve the likelihood that operator recovery actions are successful. An example of a satisfactory portable system would be one consisting of portable fans and flexible ductwork. The fans could be located in strategic locations throughout the plant, such as near the control room and DC equipment rooms and outside the ESF pump rooms. Because many of the core damage accident scenarios examined in this study are initiated by a loss of offsite power or can evolve into a station blackout situation, it may be prudent to provide portable dcpowered fans. 
5.4 Alternative 4 - Alternative 4 includes all the elements of Alternative 3 plus (1) installation of thermal barriers between heat-producing components and thermal-sensitive components, (2) installation of a permanent backup cooling system, (3) measurement of electrical cabinet temperature, and (4) performing an airfiow path test program.

This alternative has higher costs, and higher benefits than the other alternatives examined in this study. This alternative involves all the resolution elements described in Section 3.

There is no practical recovery from loss of the emergency diesel generator ventilation system because the time is too short. A method of insulating the emergency diesel generator control equipment from the diesel engine could increase the time available to effect recovery actions or return the ventilation system to operable status. A thermal barrier could effectively reduce the room heatup rate in the vicinity of the emergency diesel generator control equipment. At many plants, this modification could be performed without major redesign of the emergency diesel generator enclosures, except when the control equipment is too close to the diesel engine or there is insufficient space in the emergency diesel generator enclosure.

Installation of permanent backup HVAC/room cooling capabilities for vulnerable rooms and areas is more costly but a more effective method of improving room cooling reliability than installation of portable room cooling equipment. A backup room cooling system could be installed to remove heat from ESF pump rooms and dc equipment rooms, switchgear rooms, and control rooms. However, it is most unlikely that this element would be applied to the ESF pump rooms because of the difficulties in installing a redundant HVAC system for these rooms because of the space limitations.

Temperatures within the electrical cabinets are measured to determine the actual difference between the internal temperatures and the outside room ambient temperatures. Temperature differences provide insights on whether improvements are needed for the heat rejection capabilities of potentially vulnerable cabinets. Portable or permanent backup cooling equipment could be provided to cope with potential overheating, or existing components could be replaced with those that are less sensitive to high temperatures.

It is also important to identify areas that are not receiving sufficient airflow to remove heat generated by electrical components. Relatively simple airflow detection equipment could be used to perform airflow path tests. The objective would be to detect "dead spots" or areas where there is little or no air circulation. If "dead spots" are detected, relatively simple fixes could be implemented, including installing airflow deflectors to redirect airflow past dead spots, installing additional fans in the rooms to enhance air circulation, or modifying the airflow balance.

\subsection{Benefit Analysis}

The approach to this analysis was to modify the risk calculation model used in the PRA calculations performed in the previous sections. Modifications were made to the models at the cut set level. The modifications represent the potential improvements in HVAC/room cooling system reliability and the abilities of operators to recover from a loss of one of these functions that are anticipated to result from implementation of the resolution alternatives. The analys is primarily focuses on the risk reduction achievable 
at a typical PWR. Risk reduction at other plant types should not be appreciably different.

A summary of the affected CDF and public risk values calculated for each alternative is presented in Table 5.1. The table shows the results of the calculations performed for internal events initiated by room cooler failures, internal events initiated by transients and LOCAs that involved room coolers as contributing events, and for external events.

\subsection{Cost Analysis}

In order to estimate the costs for the various resolution alternatives, several sources were consulted (Ref. 1). Some estimates were derived from a NRC sponsored research report and supporting documents (Ref. 28). Still another source was discussions with vendors and utilities.

\subsubsection{Onsite Consequences}

Four categories of onsite consequences have been estimated in this study, based on the methodology as described in Reference 17: (1) increased occupational exposures, (2) averted occupational exposures due to reduce accidents, (3) averted onsite property damage because of reduced accidents, and (4) averted offsite property damage due to reduced accidents. These consequences are discussed below.

\subsubsection{Occupational Exposures}

This cost category deals with the increased occupational exposures that are required to implement, operate, and maintain the resolution alternatives. It includes such items as increased occupational exposures resulting from the installation of equipment, e.g., redundant pump room coolers, as well as the increased occupational exposures required to test, inspect, and maintain the redundant room coolers.

The increased occupational exposures are a function of the labor requirements in radiation zones and the average radiation dose rate in the area under consideration. A summary of the total resource requirements, radiation dose rates, and total occupational exposures for each resolution alternative is presented in Table 5.2.

\subsubsection{Averted Occupational Exposures from a Reduction in Accidents}

Reduced CDFs and thus fewer accidents, would result in averted occupational exposures if the resolutions were implemented at the plants. Averted occupational exposures are calculated according to the following equation:

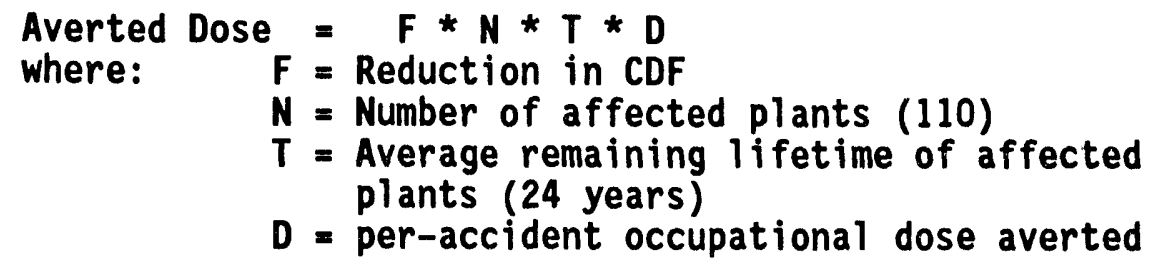


Immediate doses are assumed to occur at the time of the accident and during the immediate management of the emergency. Long-term doses result from cleanup and refurbishment or decommissioning of the damaged facility. The results of the calculations are as follows:

Resolution Alternative 1: N/A

Resolution Alternative 2:

Total Dose $=(2.4 E-06 / R Y)(110$ plants $)(24 \mathrm{yrs})(2.1 \mathrm{E}-04$ person-rem/event) $=133$ person rem

Resolution Alternative 3:

Total Dose $=(4.5 E-06 / R Y)(110$ plants $)(24$ yrs $)(2.1 E-04$ person-rem/event $)$ $=249$ person-rem

Resolution Alternative 4:

Total Dose $=(6.7 E-06 / R Y)(110$ plants $)(24$ yrs)(2.1E-04 person-rem/event) $=371$ person-rem

\subsubsection{Averted Onsite Property Damage}

Onsite property damage costs from an accident are the economic costs for the damage to plant, equipment, land, and material within the boundary of the affected site. Onsite costs consist of three categories: property interdiction or decontamination costs, replacement power costs, and capital costs of damaged plant equipment. The averted onsite damage costs are calculated using the following equation (Ref. 28):

where:

$$
V=F * N * U
$$

$$
\begin{aligned}
\mathbf{V}= & \text { Impact of averted onsite property damage (\$) } \\
\mathbf{N}= & \text { Number of affected plants } \\
\mathbf{F}= & \text { Reduction in CDF (events/RY) } \\
\mathbf{U}= & \text { Present value of property damage, conditional } \\
& \text { on occurring (\$/event) }
\end{aligned}
$$

Generic estimates for cleanup, repair, refurbishment, and replacement power costs were discounted at 5 and $10 \%$ rates to 1993 . The generic costs are shown in Table 5.3 .

\subsubsection{Averted Public Property Damage}

Averted public, or offsite, property damage represents the costs saved by reducing accidents that may affect offsite property. The impact of averted public property damage is calculated as follows (Ref. 28):

where:

$$
V 1=F * N * D
$$

$$
\begin{aligned}
V_{1} & =\text { Averted offsite property damage } \\
\mathbf{N} & =\text { Number of affected plants }
\end{aligned}
$$




$$
\begin{aligned}
F= & \text { Reduction in CDF (events/RY) } \\
D= & \text { Present value of offsite property damage } \\
& \text { conditional upon release ( } \$ / \text { event) }
\end{aligned}
$$

Table 5.4 summarizes the averted offsite property damage cost estimates.

\subsubsection{Total Costs for Resolution Alternatives}

The total costs of implementation, operation, and maintenance of the alternative resolutions to this safety issue were calculated by combining the elemental costs discussed in previous sections for each alternative and then multiplying by the number of plants and their average remaining lifetime. The cost estimates were then discounted in accordance with the guidelines in Reference 28. The results are the nuclear industries total life cycle costs for each alternative. The current values for the number of plants and average remaining lifetime are 110 plants and 24 years, respectively (Ref. 1). These values incorporate all PWRs and BWRs. There are no distinctions made between elements best applied to one plant type or the other. Therefore, the costs of each alternative were assumed to be applicable to both plant types. The resolution alternatives' costs, benefits, and value/impact ratios are shown in Tables 5.5, 5.6, 5.7, and 5.8.

\subsection{Uncertainty}

Uncertainty is expressed as a quantitative bounding of the mean value. Uncertainty arises from selection of the data bases used to determine the parameter values, assumptions, modeling, and completeness of tho analysis.

Although a complete analys is of all data uncertainties was not conducted, uncertainty studies were performed on selected issues that were important to the results. Uncertainty data were collected, evaluated, and reported in the form of distributions for these selected issues. The data gathering and reduction was used to gauge the effects of the individual data uncertainty on the final CDF results of the analysis.

The primary areas of uncertainty exist in the determination of the initiating frequency, modeling, and failure data. Each of these particular areas was addressed, and the final result combines these issues to present the uncertainty of the CDF (Ref. 1). 
5.1 Summary of CDF and Public Risks of Alternative Resolutions

\begin{tabular}{|c|c|c|}
\hline Alternative & $\begin{array}{c}\text { Affected } \\
\text { CDF, per RY }\end{array}$ & $\begin{array}{c}\text { Affected Public } \\
\text { Risk, person-rem/RY }\end{array}$ \\
\hline $\begin{array}{l}\text { Base-Case } \\
\text { Initiators } \\
\text { Contributors } \\
\text { External }\end{array}$ & $\begin{array}{l}2.04 E-06 \\
2.05 E-06 \\
8.19 E-06\end{array}$ & $\begin{array}{l}3.95 \mathrm{E}-01 \\
1.31 \mathrm{E}+00 \\
5.58 \mathrm{E}+00\end{array}$ \\
\hline TOTAL & $1.23 E-05$ & $7.28 E+00$ \\
\hline Alternative 1 & $N / A$ & $N / A$ \\
\hline $\begin{array}{l}\text { Alternative } 2 \\
\text { Initiators } \\
\text { Contributors } \\
\text { External }\end{array}$ & $\begin{array}{l}1.22 \mathrm{E}-06 \\
1.28 \mathrm{E}-06 \\
7.40 \mathrm{E}-06\end{array}$ & $\begin{array}{l}2.49 \mathrm{E}-01 \\
7.55 \mathrm{E}-01 \\
5.04 \mathrm{E}+00\end{array}$ \\
\hline TOTAL & $9.90 E-06$ & $6.04 E+00$ \\
\hline $\begin{array}{l}\text { Alternative } 3 \\
\text { Initiators } \\
\text { Contributors } \\
\text { External }\end{array}$ & $\begin{array}{l}6.43 E-07 \\
9.83 \mathrm{E}-07 \\
6.20 \mathrm{E}-06\end{array}$ & $\begin{array}{l}1.25 E-01 \\
6.15 E-01 \\
4.22 E+00\end{array}$ \\
\hline TOTAL & $7.83 \mathrm{E}-06$ & $4.96 E+00$ \\
\hline $\begin{array}{l}\text { Alternative } 4 \\
\text { Initiators } \\
\text { Contributors } \\
\text { External }\end{array}$ & $\begin{array}{l}7.89 E-09 \\
5.14 E-07 \\
5.10 E-06\end{array}$ & $\begin{array}{l}1.53 E-03 \\
3.14 E-01 \\
3.47 E+00\end{array}$ \\
\hline TOTAL & $5.62 E-06$ & $3.79 E+00$ \\
\hline
\end{tabular}


Table 5.2 Estimated Occupational Exposures for Implementation, Operation, and Maintenance of Resolution Alternatives

\begin{tabular}{|c|c|c|c|c|c|}
\hline \multirow[b]{2}{*}{$\begin{array}{l}\text { Resolution } \\
\text { Alternative }\end{array}$} & \multicolumn{2}{|c|}{ Per-plant Labor in Radiation Zones } & \multirow[b]{2}{*}{$\begin{array}{c}\text { Area Dose Rate, } \\
\mathrm{mrem} / \mathrm{hr}\end{array}$} & \multicolumn{2}{|c|}{ Per-plant Occupational Exposure } \\
\hline & $\begin{array}{l}\text { Implementation, } \\
\text { man-hr/plant }\end{array}$ & $\begin{array}{c}\text { Operation/Maint. } \\
\text { man-hr/RY }\end{array}$ & & $\begin{array}{l}\text { Implementation, } \\
\text { person-rem/plant }\end{array}$ & $\begin{array}{l}\text { Operation/Maint. } \\
\text { Person-rem/RY }\end{array}$ \\
\hline 1 & $\mathbf{N} / \mathbf{A}$ & N/A & N/A & N/A & $N / A$ \\
\hline 2 & 0 & 4 & 10 & 0 & 0.04 \\
\hline 3 & 320 & 28 & 10 & 3.2 & 0.28 \\
\hline 4 & 8,000 & 68 & 10 & 80.0 & 0.68 \\
\hline
\end{tabular}

NOTE: Basic resource requirements are provided in Section 5 for each element of the resolution alternatives. 
Table 5.3 Summary of Averted Onsite Property Damage Costs

\begin{tabular}{|c|c|c|c|c|c|}
\hline $\begin{array}{l}\text { Resolution } \\
\text { Alternative }\end{array}$ & $\begin{array}{l}\text { Discount } \\
\text { Rate, \% }\end{array}$ & $\underset{\text { events/RY }}{\text { F }}$ & $\mathbf{N}$ & $\underset{\text { \$/event }}{U}$ & $\mathbf{v}$ \\
\hline 1 & N/A & N/A & N/A & N/A & $N / A$ \\
\hline 2 & $\begin{array}{r}5 \\
10\end{array}$ & $\begin{array}{l}2.4 E-06 \\
2.4 E-06\end{array}$ & $\begin{array}{l}110 \\
110\end{array}$ & $\begin{array}{l}2.03 E+10 \\
1.01 E+10\end{array}$ & $\begin{array}{l}5.4 E+06 \\
2.7 E+06\end{array}$ \\
\hline 3 & $\begin{array}{r}5 \\
10\end{array}$ & $\begin{array}{l}4.5 E-06 \\
4.5 E-06\end{array}$ & $\begin{array}{l}110 \\
110\end{array}$ & $\begin{array}{l}1.60 E+10 \\
7.64 E+09\end{array}$ & $\begin{array}{l}7.9 E+06 \\
3.8 E+06\end{array}$ \\
\hline 4 & $\begin{array}{r}5 \\
10\end{array}$ & $\begin{array}{l}6.7 E-06 \\
6.7 E-06\end{array}$ & $\begin{array}{l}110 \\
110\end{array}$ & $\begin{array}{l}1.39 E+10 \\
6.53 E+09 *\end{array}$ & $\begin{array}{l}1.0 E+07 \\
4.8 E+06\end{array}$ \\
\hline
\end{tabular}


Table 5.4 Summary of Averted Offsite Property Damage Costs

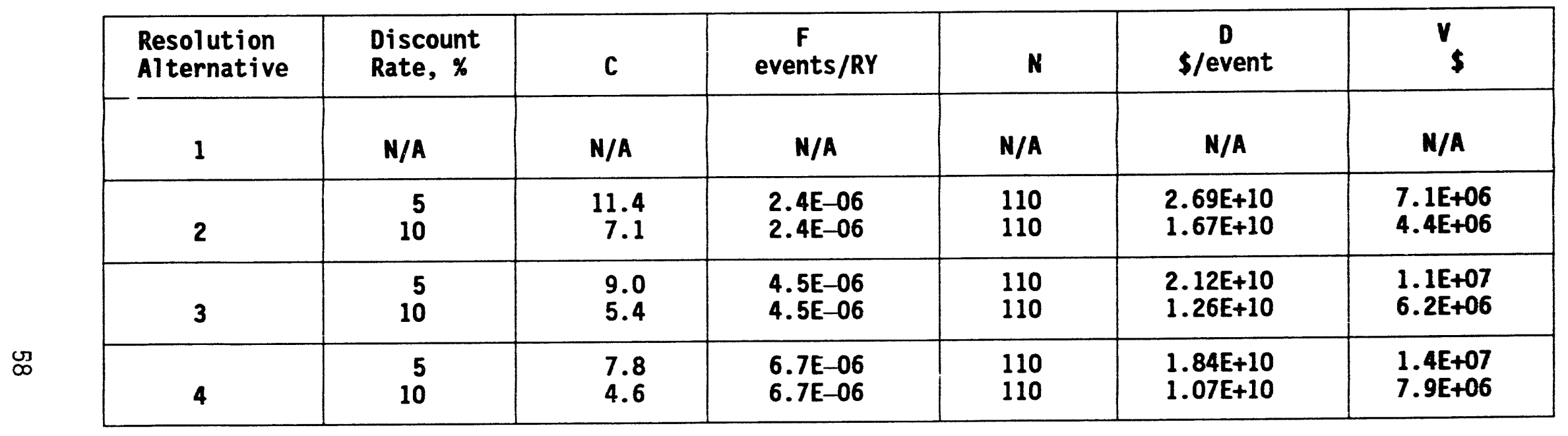


Table 5.5 Summary of Cost Estimates for Each Resolution Element

\begin{tabular}{|c|c|c|c|c|}
\hline \multicolumn{2}{|c|}{ Alternative } & \multirow{2}{*}{$\frac{\text { Resolution Element }}{\text { N/A }}$} & \multirow{2}{*}{$\begin{array}{c}\text { Implementation } \\
\text { Costs, } \$ \\
\text { Per plant }\end{array}$} & \multirow{2}{*}{$\begin{array}{c}\begin{array}{c}\text { Operation/ } \\
\text { Maintenance } \\
\text { Costs, } \$\end{array} \\
\text { N/A }\end{array}$} \\
\hline \multirow{11}{*}{4} & 1 & & & \\
\hline & & 1. Heatup, fragility analysis & 150,000 & 0 \\
\hline & & 2. Design review & 54,500 & 0 \\
\hline & & $\begin{array}{l}\text { 3. Enhanced preventive maintenace } \\
\text { and testing }\end{array}$ & 20,000 & 2,270 \\
\hline & & 4. Improve emergency procedures & 16,620 & 0 \\
\hline & & 5. Remote temperature monitoring & 100,000 & 908 \\
\hline & & 6. Install portable coolers & 10,000 & 454 \\
\hline & & 7. Install permanent coolers & 626,400 & 2,270 \\
\hline & & 8. Install thermal barriers & 63,000 & 0 \\
\hline & & 9. Electrical cabinet tests & 61,480 & 0 \\
\hline & & 10. Airflow measurements & 61,480 & 0 \\
\hline
\end{tabular}


Table 5.6 Summary of Benefits of Alternative Resolutions

\begin{tabular}{|c|c|c|c|c|}
\hline \multirow[b]{2}{*}{ Parameter } & \multicolumn{4}{|c|}{ Resolution Alternative } \\
\hline & 1 & 2 & 3 & 4 \\
\hline $\begin{array}{l}\text { Per-plant reduction in core damage } \\
\text { frequency (per RY) }\end{array}$ & $N / A$ & $2.4 E-06$ & $4.5 E-06$ & $6.7 E-06$ \\
\hline $\begin{array}{l}\text { Per-plant reduction in public risks } \\
\text { (person-rem/RY) }\end{array}$ & $N / A$ & $1.2 E+00$ & $2.3 E+00$ & $3.5 E+00$ \\
\hline $\begin{array}{l}\text { Total integrated risk reduction } \\
\text { (person-rem) }\end{array}$ & $N / A$ & $3.3 E+03$ & $5.2 E+03$ & $9.4 E+03$ \\
\hline
\end{tabular}


Table 5.7 Summary of Per-Plant and Total Costs for Each Resolution Alternative

\begin{tabular}{|c|c|c|c|c|c|c|c|c|}
\hline \multicolumn{9}{|c|}{ PER-PLANT COSTS ( $\$ / p l a n t)$} \\
\hline \multirow{2}{*}{$\begin{array}{l}\text { Resolution } \\
\text { Alternative }\end{array}$} & \multirow{2}{*}{$\begin{array}{l}\text { Discount } \\
\text { Rate, \% }\end{array}$} & \multirow{2}{*}{$\begin{array}{l}\text { Implemen- } \\
\text { tation } \\
\text { Costs }\end{array}$} & \multirow{2}{*}{$\begin{array}{l}\text { Operation/ } \\
\text { Maintenance } \\
\text { Costs }\end{array}$} & \multirow[b]{2}{*}{ NRC Cost } & \multicolumn{2}{|c|}{ Onsite Consequences } & \multirow{2}{*}{$\begin{array}{l}\text { Averted } \\
\text { Onsite } \\
\text { Damage }\end{array}$} & \multirow{2}{*}{$\begin{array}{l}\text { Averted } \\
\text { Offsite } \\
\text { Damage }\end{array}$} \\
\hline & & & & & Person-rem & $\$ / p l$ ant & & \\
\hline 1 & N/A & N/A & N/A & N/A & N/A & $N / A$ & N/A & $N / A$ \\
\hline $\begin{array}{l}2 \\
3\end{array}$ & $\begin{array}{r}5 \\
10 \\
5 \\
10\end{array}$ & $\begin{array}{l}2.2 E+05 \\
2.0 E+05 \\
2.9 E+05 \\
2.4 E+05\end{array}$ & $\begin{array}{l}2.7 E+04 \\
1.7 E+04 \\
3.7 E+04 \\
2.1 E+04\end{array}$ & $\begin{array}{l}2.2 E+04 \\
1.7 E+04 \\
2.2 E+04 \\
1.7 E+04\end{array}$ & $\begin{array}{l}9.6 \mathrm{E}-01 \\
9.6 \mathrm{E}-01 \\
9.9 \mathrm{E}+00 \\
9.9 \mathrm{E}+00\end{array}$ & $\begin{array}{l}9.6 \mathrm{E}+02 \\
9.6 \mathrm{E}+02 \\
9.0 \mathrm{E}+03 \\
9.9 \mathrm{E}+03\end{array}$ & $\begin{array}{l}4.9 E+04 \\
2.4 E+04 \\
7.2 E+04 \\
3.4 E+04\end{array}$ & $\begin{array}{l}6.5 E+04 \\
4.0 E+04 \\
9.5 E+04 \\
5.7 E+04\end{array}$ \\
\hline 4 & $\begin{array}{r}5 \\
10\end{array}$ & $\begin{array}{l}9.1 E+05 \\
7.2 E+05\end{array}$ & $\begin{array}{l}5.6 E+04 \\
3.1 E+04\end{array}$ & $\begin{array}{l}4.9 E+04 \\
3.7 E+04\end{array}$ & $\begin{array}{l}9.6 E+01 \\
9.6 E+01\end{array}$ & $\begin{array}{l}9.6 E+04 \\
9.6 E+04\end{array}$ & $\begin{array}{l}9.4 E+04 \\
4.4 E+04\end{array}$ & $\begin{array}{l}1.2 E+05 \\
7.2 E+04\end{array}$ \\
\hline \multicolumn{9}{|c|}{ TOTAL COSTS (\$) } \\
\hline $\begin{array}{l}\text { Resolution } \\
\text { Alternative }\end{array}$ & $\begin{array}{l}\text { Discount } \\
\text { Rate, \% }\end{array}$ & N & $\begin{array}{l}\text { Implement- } \\
\text { tation } \\
\text { Cost }\end{array}$ & $\begin{array}{c}\text { Include } \\
\text { Operation/ } \\
\text { Maintenance } \\
\text { Cost }\end{array}$ & $\begin{array}{l}\text { Include } \\
\text { NRC Cost }\end{array}$ & $\begin{array}{c}\text { Include } \\
\text { Onsite } \\
\text { Consequences }\end{array}$ & $\begin{array}{l}\text { Include } \\
\text { Averted } \\
\text { Onsite } \\
\text { Damage }\end{array}$ & $\begin{array}{l}\text { Include } \\
\text { Averted } \\
\text { Offsite } \\
\text { Damage }\end{array}$ \\
\hline 1 & N/A & N/A & N/A & N/A & N/A & $\mathbf{N} / \mathbf{A}$ & N/A & $\mathbf{N} / \mathbf{A}$ \\
\hline 2 & $\begin{array}{r}5 \\
10\end{array}$ & $\begin{array}{l}110 \\
110\end{array}$ & $\begin{array}{l}2.4 E+07 \\
2.2 E+07\end{array}$ & $\begin{array}{l}2.7 E+07 \\
2.4 E+07\end{array}$ & $\begin{array}{l}3.0 \mathrm{E}+07 \\
2.6 \mathrm{E}+07\end{array}$ & $\begin{array}{l}3.0 \mathrm{E}+07 \\
2.6 \mathrm{E}+07\end{array}$ & $\begin{array}{l}2.4 E+07 \\
2.3 E+07\end{array}$ & $\begin{array}{l}1.7 E+07 \\
1.9 E+07\end{array}$ \\
\hline 3 & $\begin{array}{r}5 \\
10\end{array}$ & $\begin{array}{l}110 \\
110\end{array}$ & $\begin{array}{l}3.2 \mathrm{E}+07 \\
2.6 \mathrm{E}+07\end{array}$ & $\begin{array}{l}3.6 \mathrm{E}+07 \\
2.9 \mathrm{E}+07\end{array}$ & $\begin{array}{l}3.8 E+07 \\
3.1 E+07\end{array}$ & $\begin{array}{l}3.9 E+07 \\
3.2 E+07\end{array}$ & $\begin{array}{l}3.2 E+07 \\
2.8 E+07\end{array}$ & $\begin{array}{l}2.1 E+07 \\
2.2 E+07\end{array}$ \\
\hline 4 & $\begin{array}{r}5 \\
10\end{array}$ & $\begin{array}{l}110 \\
110\end{array}$ & $\begin{array}{l}1.0 \mathrm{E}+08 \\
7.9 \mathrm{E}-07\end{array}$ & $\begin{array}{l}1.1 E+08 \\
8.3 E+07\end{array}$ & $\begin{array}{l}1.1 E+08 \\
8.7 E+07\end{array}$ & $\begin{array}{l}1.2 E+08 \\
9.8 E+07\end{array}$ & $\begin{array}{l}1.1 E+08 \\
9.3 E+07\end{array}$ & $\begin{array}{l}9.9 E+07 \\
8.5 E+07\end{array}$ \\
\hline
\end{tabular}


Table 5.8 Best-Estimate Value: Impact Ratios ( $\$ /$ person-rem)

\begin{tabular}{|c|c|c|c|}
\hline $\begin{array}{l}\text { Resolution } \\
\text { Alternative }\end{array}$ & $\begin{array}{l}\text { Discount } \\
\text { Rate, \% }\end{array}$ & Cost: ${ }^{\text {Net }}$ Benefit & $\begin{array}{l}\text { Total } \\
\text { Cost: Benefit }\end{array}$ \\
\hline 1 & N/A & N/A & N/A \\
\hline 2 & $\begin{array}{r}5 \\
10\end{array}$ & $\begin{array}{l}5.2 E+03 \\
5.7 E+03\end{array}$ & $\begin{array}{l}9.0 \mathrm{E}+03 \\
7.8 \mathrm{E}+03\end{array}$ \\
\hline 3 & $\begin{array}{r}5 \\
10\end{array}$ & $\begin{array}{l}3.4 \mathrm{E}+03 \\
3.5 \mathrm{E}+03\end{array}$ & $\begin{array}{l}6.4 \mathrm{E}+03 \\
5.1 \mathrm{E}+03\end{array}$ \\
\hline 4 & $\begin{array}{r}5 \\
10\end{array}$ & $\begin{array}{l}1.0 E+04 \\
9.0 E+03\end{array}$ & $\begin{array}{l}1.3 E+04 \\
1.0 E+04\end{array}$ \\
\hline
\end{tabular}




\section{DECISION RATIONALE}

This generic issue was initiated as the result of the Advisory Committee on Reactor Safeguard's (ACRS's) recommendation based on an NRC staff report presented in a 1986 ACRS meeting. The staff reported that failures of the cooling system for areas containing safety-related components in certain nuclear power plants could contribute significantly to the estimated CDF. (The "high" estimated CDF as suggested in the 1986 staff report was based on the assumption that no credit was given for operator actions or equipment testing.) The issue was prioritized and given a "High" priority. Pacific Northwest Laboratories was then engaged as the principal investigator for the generic issue.

As discussed in Sections 4 and 5 , the affected CDF from HVAC/room cooler failure was relatively small (approximately $1.3 \mathrm{E}-05 / \mathrm{RY}$ ), and the reduction in the affected CDF was only marginal (on the order of 4.0E-06/RY). The low affected CDF value was primarily because the fact that the operator often had sufficient time to mitigate the fault(s) or initiate corrective actions before the reactor core could be damaged (Refs. $23,24, \& 25$ ). The value/impact analysis further indicated that the cost benefit ratio was well above the $\$ 1000 /$ person-rem guideline for all the alternatives except Alternative 1, "No Action."

On the basis of the results of the CDF analysis, the value impact analysis, and PNL's evaluation of the available data it is concluded that no backfit to reduce the public risks associated with HVAC/room cooling system is warranted at this time, and Alternative 1 should be adopted (Refs. 29, 30). This conclusion is based on the following considerations.

1. Although it appears that the average affected CLF for the population of plants is in the 1E-05 to 1E-06/RY range, there appear to be some plantspecific accident sequences that may be as high as $1 E-04 / R$ '. In most cases, the high-frequency plant-specific accident sequences wers shown to be either highly conservative or to have been significantly reauced through hardware or operational changes. As shown in previous sections, the PRAs being performed in support of IPEs have identified plant-specific anomalies and hardware configurations that have been or will be resolved. Participation in the IPE program should be sufficient for licensees to identify and resolve HVAC and room-cooler related issues that are safety significant.

2. Alternative 2, which involves studies designed to define, evaluate, and prioritize, on a plant specific basis, the potential vulnerabilities to loss of HVAC and room cooling system, seeks to improve procedural and maintenance/test programs. Alternative 2 shows a net cost-benefit ratio of approximately $\$ 5200 /$ person-rem. This alternative is the minimum-cost, minimum-benefit alternative. Although a relatively large reduction in CDF was observed for station blackout leading to reactor coolant pump seal LOCA, this is primarily because of the improved reliability of component cooling water pump room coolers and the enhanced abilities of operators to recover from failed room cooling systems. Overall, the affected CDF would be reduced by about $20 \%$ as a result of Alternative 2 . 
3. Alternative 3 involves installation of remote temperature-monitoring systems in the most vulnerable areas; purchase and installation of portable cooling equipment to improve the likelihood for success in operator recovery actions; plus the elements described in Alternative 2. The affected CDF for this alternative was calculated to be about $36 \%$ lower than the base-case affected CDF. The HVAC or room cooler initiator sequences would be reduced by about $68 \%$, and the contributors by about $50 \%$. As with Alternative 2, the smallest reduction in CDF for this alternative would result from external events. Overall, the reduction in CDF for Alternative 3 amounts to a very small reduction from the original CDF (Ref. 1).

4. Alternative 4 would have the highest costs, and the highest benefits of the alternatives examined in this study. It would involve the installation of permanent backup HVAC or room cooling capabilities for vulnerable rooms and areas, installation of thermal barriers for the emergency diesel generator control equipment; plus the elements in Alternatives 2 and 3 . Where space is permitted, a backup room cooling system would be installed to remove heat from ESF pump rooms and possibly dc equipment rooms, switchgear rooms, and control rooms. It also addresses vulnerabilities related to failure of the emergency diesel generator ventilation system. Because of the very short recovery time, there are no practical operator actions to mitigate the effects of loss of the emergency diesel generator ventilation system. A thermal barrier could effectively reduce the room heatup rate in the vicinity of the emergency diesel generator control equipment and could increase the time available to effect recovery actions or return the emergency diesel generator ventilation system to operable status. The affected CDF for Alternative 4 would be about $54 \%$ lower than the base-case CDF. The HVAC or room cooler initiator sequences would be reduced to insignificant levels and the contributors reduced by about $75 \%$. The affected CDF from external events would be reduced by $37 \%$. Overall, the reduction in CDF for Alternative 4 would amount to a very small reduction in the original CDF (Ref. 1).

5. Based on the information available and plant operating experience, it appears that the currently available regulatory guidelines are adequate to ensure safe shutdown of the reactor in the event of a HVAC/room cooling system failure. These guidelines are:

a) Regulatory Guide 1.52, "Design, Testing, and Maintenance Criteria for Post accodent Engineered-Safety-Feature Atmosphere Cleanup System Air Filtration and Adsorption Units of Light-Water-Cooled Nuclear Power Plants."

b) Regulatory Guide 1.140, "Design, Testing, and Maintenance Criteria for Normal Ventilation Exhaust System Air Filtration and Adsorption Units of Light-Water-Cooled Nuclear Power Plants."

c) Standard Review Plan 9.4.1, "Control Room Area Ventilation Systelii."

d) Standard Review Plan 9.4.2, "Spent Fuel Area Ventilation System."

e) Standard Review Plan 9.4.3, "Auxiliary and Radwaste Area Ventilation System."

f) Standard Review Plan 9.4.4, "Turbine Area Ventilation system." 


\section{IMPLEMENTATION}

No regulatory action for resolution of this issue is required for the currently existing nuclear power plants or for the new plants not yet in operation. This regulatory analysis and the PNL report in support of this regulatory analysis will be made publicly available as part of the normal distribution. 


\section{REFERENCES}

1. Daling, P. M. et al., "Assessment of Affected Core Damage Frequency and Public Risks Associated with Generic Issue 143 - Availability of HVAC and Chilled Water Systems," (NUREG/CR-6086), April 1993.

2. "Staff Evaluation of Millstone 3 Individual Plant Examination (IPE) Internal Events, GL 88-20," May 5, 1992.

3. "Individual Plant Examination" for Severe Accident Vulnerabilities in Response to GL 88-20, Palo Verde Nuclear Power Station Units 1, 2 and 3, April 28, 1992.

4. Chiramal, M. "Effects of Ambient Temperature on Electronic Components in Safety-Related Instrument and Control Systems," Case Study Report AEOD/6604, December 1986.*

5. NRR Staff Presentation to the ACRS, "Chilled Water System/Room Cooling Results from PRAs," June 27, 1986.*

6. "Severe Accident Risks: An Assessment for Five U.S. Nuclear Power Plants," NUREG-1150, December 1990.

7. Toledo Edison Company, LER 82-051, Docket No. 50-346, October 20, 1982.

8. Arizona Nuclear Power Project, LER 85-083, Docket No. 50-528, January 15, 1986.

9. South Carolina Electric \& Gas Company, LER 82-016, Rev. 2, Docket No. 50-395, January 13, 1983.

10. Daling, P. M. et al., "Prioritization Analysis for Generic Issue 143; Availability of Chilled Water Systems and Room Cooling," January 1991.*

11. Memorandum for ACRS Members from J. C. MCKinley, "Certification of Minutes of the June 27, 1986 Joint Meeting of the ACRS Subcommittees on Occupational and Environmental Protection Systems/Auxiliary Systems," August 6, 1987.*

12. Letter to V. Stello from W. Kerr, "ACRS Comments on Nuclear Power Plant Air Cooling Systems," October 15, 1987.*

13. INPO Significant Event Report (SER) 11-92, "Consequences of Disabled Dampers," Ju1y 13, 1992.*

14. Gregory, J. J. et al., "Evaluation of Severe Accident Risks: Sequoyah Unite 1," NUREG/CR-4551, Vo1. 5, Rev 1, Sandia National Laboratories, Albuquerque, New Mexico, 1990.

* Available in the NRC Public Document Room under NUREG-1421 
15. "Analysis of Core Damage Frequency From Internal Events: Methodology Guide Lines, Vol. 1, NUREG/CR-4551, April 1989.

16. "Recovery Actions in PRA for the Risk Methods Integration and Evaluation Programs (RMIEP)," NUREG/CR-4834, 1987.

17. Lambright, J. A., et al., "Analysis of Core Damage Frequency: Peach Bottom, Unit 2 External Events," NUREG/CR-4550, Vol. 4, 1990.

18. Memorandum from E. S. Beckjord, RES Office Letter No. 2, "Procedures for obtaining Regulatory Impact Analysis Review and Support," November 18, 1998.*

19. Memorandum from E. S. Beckjord to Distribution, RES Office Letter No. 3, "Procedure and Guidance for the Resolution of Generic Issues," May 10, 1998.*

20. "Individual Plant Examination," Forward Response to Generic Letter 8820, Oconee Nuclear Station Units 1, 2, and 3, November 30, 1990.

21. Drouin, M. T., et al., "Analysis of Core Damage Frequency: "Grand Gulf Unit 1 Internal Events," NUREG/CR-4550, Vo1. 6, September 1987.

22. "Complete CONCISE Printout for Model 148-PWR-ME (A3-ME) Energy Economic Data Base (EEDB) Phase IX Update," Volume 2 of 9, Plant Set 2 of 3, 7697.9000, DOE Report 871102, 1987.

23. Gulf States Utilities Co., LER 92-024-02, Docket No.50-458, March 1, 1993.

24. Pacific Gas \& Electric Co., LER 92-012-01, Docket No. 50-275, April 12, 1993.

25. Baltimore Gas \& Electric Co., LER 93-001-00, Docket No. 50-317, March 9, 1993.

26. Bertucio, R. C., et al., "Analysis of Core Damage Frequency: Surry Unit 1 Internal Events," NUREG/CR-4550, Vol. 3, 1990.

27. Ramsde11, J. V., et al., "Tornado Climatology of the Contigus United States", NUREG/CR-4461, 1986.

28. Heaberl in, S. W., et a1., "A Handbook for Value-Impact Assessment," NUREG/CR-3568, PNL-4646, December 1893.*

29. "Safety Goal for the Operation of Nuclear Power Plants," Policy Statement, Federal Register, 51 FR 26044, August 4, 1986.

30. Memorandum for J. M. Taylor from C. J. Heltemes, "Commission Paper on Safety Goal Implementation," August 20, 1991.* 
31. Kirmura, C. Y., et al., "Evaluation of External Hazards to Nuclear Power Plants in the United States," NUREG/CR-5042, 1987. 


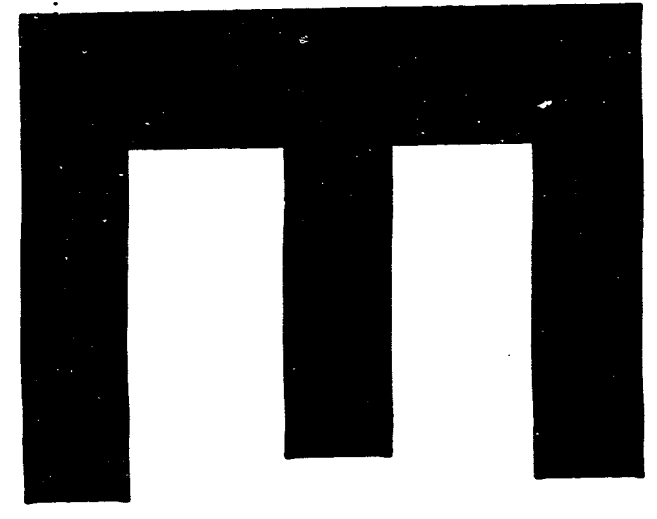

L
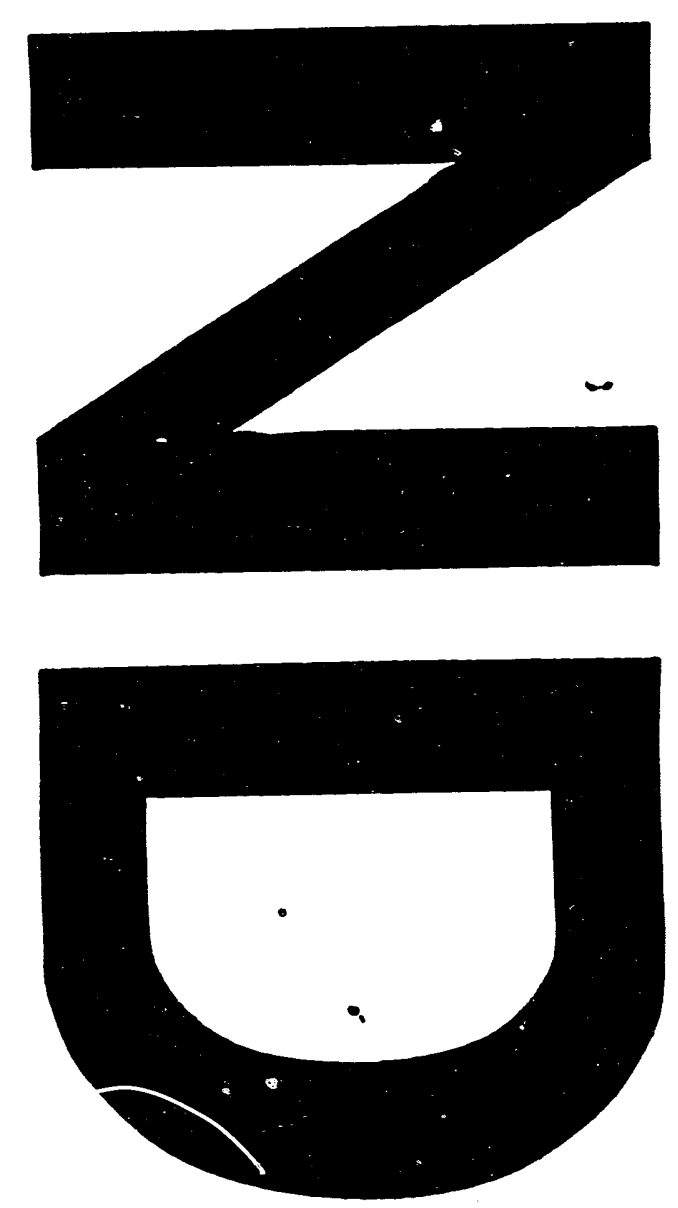
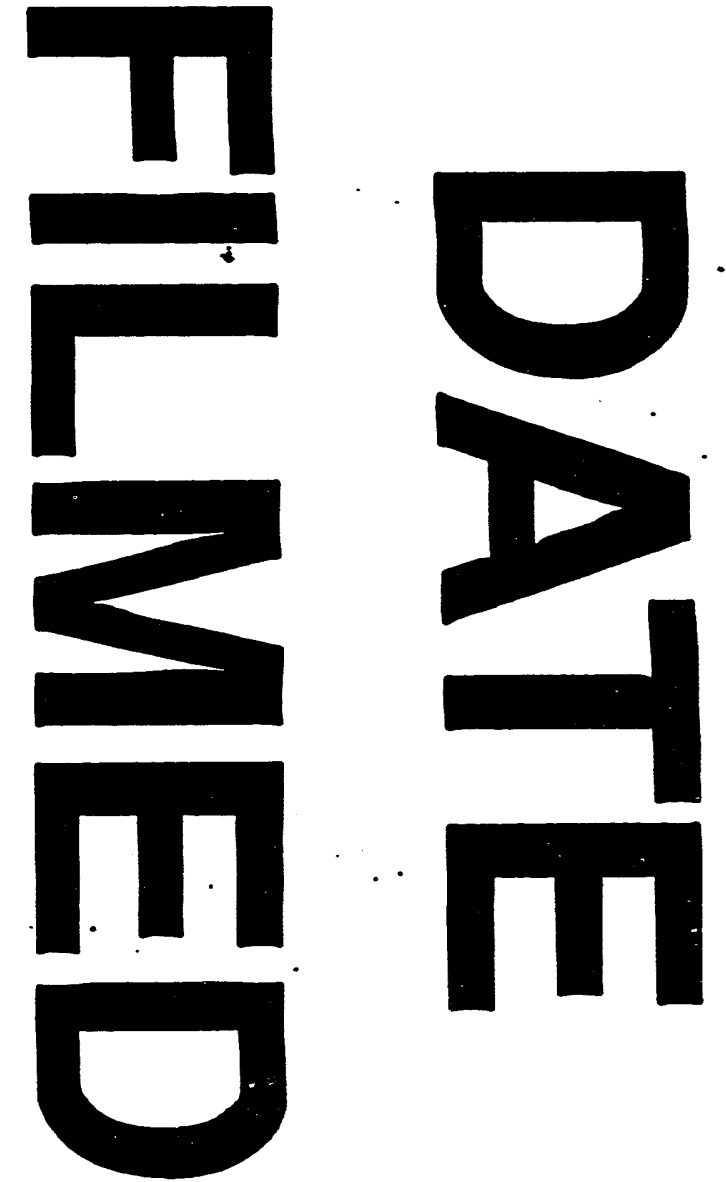

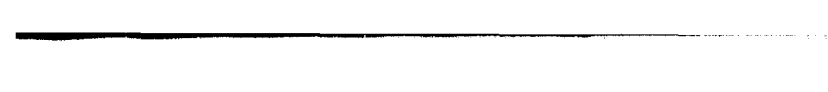